\title{
Qualitative Study of Profit Margin Determinants and Pricing Practices: An Islamic Banking Perspective
}

Fauzias Mat Nor

Faculty of Economics and Muamalat, Universiti Sains Islam

Malaysia, Malaysia

Amir Shaharuddin

Faculty of Economics and Muamalat, Universiti Sains Islam

Malaysia, Malaysia

Norhaziah Nawai

Faculty of Economics and Muamalat, Universiti Sains Islam

Malaysia, Malaysia

Ainulashikin Marzuki

Faculty of Economics and Muamalat, Universiti Sains Islam

Malaysia, Malaysia

W Zainuddin Wan Abdullah

School of Maritime Business and Management, Universiti

Malaysia Terengganu, Malaysia

*Corresponding author: fauzias@usim.edu.my

A R T I C L E I N F O

Article history:

Received 16 April 2018

Revised 13 September 2018

Accepted 20 September 2018

Keywords:

Islamic banks, Bank margin, Price setting, Pricing practice, Balance sheet.

JEL Code: B22, E44, G21
A B S T R A C T

The purpose of this study is to investigate and validate the determinants of profit margins and pricing practices of Islamic banking institutions in Malaysia. The key determinants and pricing approaches were extracted using a verbal protocol followed by probing of respondents. Focus group interviews were conducted with Islamic banking experts from Bank Muamalat Malaysia Berhad, CIMB Islamic Bank Berhad, Bank Islam Malaysia Berhad and Maybank Islamic Berhad. Preliminary analysis suggested some distinct outcomes in the identification of determinants and practices in pricing and bank margins for future research. This study has provided important insights for Islamic 
banks to improve their bank margins and profit by considering significant variables affecting profitability. Generally, the themes which emerged from the interviews concurred with findings from literature. However, the determinants that have yet to be captured in the literature are marketing strategies which include product risk, financing terms and conditions; and discretionary power. Awareness of Islamic banking products and cost of fund strategies are other important determinants of bank margins and profitability. This paper also has the potential to enhance bank margin determinants, concept, theory and practice.

\section{Introduction}

Nowadays, Islamic banking has becomes an important player in the banking industry. Increase in deregulation, globalisation, and the operating environment of the banking industry are expected to become more dynamic and competitive. Many studies have been conducted to determine factors affecting the profit of conventional and Islamic banks (Demirguc \& Huizinga, 2001; Erwin \& Rahmatina, 2010; Hameed, 2003; Jane et al., 2012; Kasmidou et al., 2005). Bank profitability has been seen as a catalyst for improving bank sustenance. Malaysia is one of the most progressive and attractive Islamic financial sectors in the world (Abduh \& Yameen, 2013). The first Islamic bank in Malaysia was established in 1983 namely, Bank Islam Malaysia Berhad (BIMB). In 1993, commercial banks, merchant banks, and finance companies started offering Islamic banking products and services under the Islamic banking scheme. However, funds need to be separated between conventional and Islamic banks. The operation of Malaysian Islamic banks alongside with conventional banks provided the challenge to Islamic banking to compete in a progressive manner. The approaches taken by Islamic banks will determine whether Islamic banking will survive in the highly competitive, global banking industry. In order to stay ahead of the competition the Islamic banking industry needs to be dynamic and proactive in designing and setting a proper plan of banking strategies. Islamic principles such as prohibition of interest should not be a hurdle in formulating and creating current and innovative customer oriented products that will spur the Islamic banking industry to greater heights. These efforts will ensure Islamic 
banks can stay competitive in the banking industry and to gain enough profit to grow. Even though, bank profitability is crucial for Islamic banks, profit achieved should be acquired according to Islamic principles which govern Islamic banking practices, such as mutual risk and profit sharing between parties, assurance of fairness for all and that all transactions are based on an underlying business activity or asset (Kamal et al., 2009). Apart from the introduction, this paper is organised based on the following sections: literature review, methodology, findings and lastly, conclusion and recommendations.

\section{Literature Review}

\subsection{Islamic Banking System in Malaysia}

Malaysia has dedicated its commitment to supporting the Islamic banking and finance industry. Bank Negara Malaysia (BNM), the central bank of the country, has been entrusted to assist and support the industry, including, its innovation and expansion which are the most important features of its policies. Consequently, this industry has established a regulatory framework, developed assets, accounting standards, and training facilities to provide skilled manpower for its rapid expansion. In fact, Malaysian banks operate on a dual banking system, whereby, the comprehensive Islamic banking system operates in parallel with the conventional banking system (Haron \& Shanmugam, 1997; Ilias, 2009). In other words, separate Islamic banking regulations exists side by side with those of conventional banks. Additionally, the system is well protected by having an effective legal framework, as well as distinctive players in banking, capital market and takaful sectors (Hassan, 2007). The legal framework for Islamic banks is governed by the Islamic Financial Services Act 2013 (IFSA). It contains among others, Shariah requirements; payment systems; prudential requirements; ownership, control and transfer of business; business conduct and consumer protection; Islamic money market; and director compliance. At the global level, the Islamic Financial Services Board (IFSB), which is the equivalent of the Basel Committee on Banking Supervision for conventional banks, encourages and improves the reliability and stability of the Islamic financial services industry through establishing and regulating international prudential standards (Chong \& Liu, 2009; Marliana et al., 2011; Nadi, 2017).

\subsection{Present State of Islamic Banking Industry in Malaysia}

Malaysia is now classified as a global hub for the Islamic banking and finance sector. The success and contribution of Malaysia in developing this sector is recognised globally. Today, Malaysia has the most developed Islamic financial 
though IFSA was introduced in 2013, Islamic banks still practise the ratio deposit vs financing as practised previously, whereby the deposit structure consists of CASA, Fixed Deposit and interbank borrowing (ratio - 40\%: 30\%: 30\%). While under IFSA 2013 (ratio - 20\%: 60\%; 20\%) (focus group interviews). As proposed under IFSA 2013, now demand deposit are defined under Qard (limitation in providing returns) and Tawarruq concept under investment account. This means that the overall cost of funding incurred by Islamic banks have increased coming from a higher proportion of fixed deposits.

On the asset side, borrowing under conventional banks, will be used to give loans to interested parties. To gain profit, the interest charged to customers who borrow is higher than the interest paid to depositors. The difference between interest charged and interest paid is known as interest spread or bank profit. In Islamic banking, despite performing similar banking functions as conventional banks, it is relatively different from conventional banks due to the Islamic principles that need to be complied with. Furthermore, the mode of its intermediation is distinguished from conventional banks due to the different underlying contracts. Generally, Islamic banks can transfer (using customer deposits) funds through contracts, i.e. (1) Asset-backed/debt based transactions (tawarruq, murabahah, ijarah, istisna'), (2) Profit sharing/equity based transactions (mudharabah and musyarakah), and (3) Fee based/trade financing transactions (ujr, sarf, wakalah). In Islamic banking, every product has its own unique features and characteristics which will determine the operation of the product.

On the liability side, deposits placed in conventional banks are guaranteed of their returns to depositors, while Islamic banks cannot guarantee the returns to depositors. In terms of balance sheet classification, generally the items are demand deposit (wadiah, wakalah), unrestricted investment accounts (mudharabah) or special/restricted investment accounts (mudharabah), capital, equity, and reserve. In terms of operation, for example under the savings account contract of wadiah yad dhamanah, the bank acts as the guardian of the fund, and the bank can use the fund to generate income. However in Islamic banking, it is not compulsory to give the returns to the depositors. Returns in the form of hibah can be given to depositors upon the bank's discretion. Under the qard principle as defined by AAOIFI, qard is the contract by which the bank acts as the trustee of the fund. The bank has the right to utilise the money, but is not obliged to pay returns to the depositors. However, the bank can give a certain amount of reward by way of hibah (gift) at the bank's discretion. As for investment accounts (tawarruq), it is based on the murabahah principle, which needs to be pre-agreed in terms of cost and profit upon opening an account.

\subsection{Profit Margins and its Determinants for Islamic Banks}

The literature on determinants of Islamic banking profitability has increased over the past decade. For instance, Bashir (2003) examined factors that affected 
sector in the world that operates side by side with the conventional banking system (Chong \& Liu, 2009). As one of the countries with the most active and developed Islamic banking sector in the world, Malaysia tries to achieve sustainable growth for its Islamic banking industry. Currently, this industry plays a significant role in the economy, making up one of the biggest providers of financial services in the Malaysian economy. In addition, Islamic banks in Malaysia channel funds from the corporate to the household sector by mainly financing vehicle and residential property purchases (Karwowski, 2009). Deferred payment transactions and markup remain the dominant modes of financing (Hassan, 2007). Thus, in order for Islamic banks in Malaysia to achieve sustainable growth, significant emphasis has to be placed in providing service quality beyond merely relying on the religious loyalty of customers. By having better service quality, Islamic banks will be able to attract new customers, while maintaining the loyalty of existing customers. All these will lead to more profit, and subsequently, to sustainable growth. Besides the "interest-free banking scheme", Malaysia has a well-developed Islamic interbank money market, Islamic government debt securities market, and Islamic insurance market (Chong \& Liu, 2009). The Islamic interbank money market, set up in January 1994, permits Islamic banking institutions to do business employing designated Islamic financial mechanisms among themselves. Additionally, the Mudharabah Interbank Investments (MII) mechanism, allows a deficient Islamic banking institution to attain investment from a surplus Islamic banking institution on a mudharabah (profit-sharing) basis. Whereas, the Government Investment Issues (GII) market, which was introduced in 1983, is the Islamic equivalent of a conventional Treasury bill and bond market. In addition, the first Islamic insurance, or takaful company was established in 1984, i.e. Syarikat Takaful Malaysia Berhad, to fulfil the public's need for insurance products that are Shariah compliant. Currently there are 12 Takaful operators in Malaysia governed by IFSA 2013. To safeguard the interest of operators, a mandatory membership with the Malaysian Takaful Association (MTA) is required under the Takaful Act of 1984, which was formed in 2002. All operators are required to be members of MTA before they can start operations (Puteri et al., 2016).

\subsection{Balance Sheet Items Analysis of Islamic Banks}

In the Malaysian banking scenario, Islamic and conventional banks run side by side and compete in the banking business with their counterparts. In terms of the nature of the business, both banks run the business with a target of obtaining profit with similar banking functions, i.e. lending and borrowing. However, the principles and practices of both banks are different. Islamic banking practises more customer friendly situations (fairness) between the bank (mudarib) and customer (rabbul-mal) and vice versa, while in conventional banking, the relationship is solely based on business which is more a lender-borrower relationship. Even 
the profitability of Islamic banks in the Middle East. This was followed by other researchers such as Izahar and Asutay (2007) who used empirical techniques to analyse the performance of Bank Muamalat in Indonesia in terms of bank profitability (ROA), while Samy and Mohamed (2008) investigated the determinant effect of internal and internal factors on bank profitability. Wasiuzzaman and Hanimas (2010) examined the effect of bank specific factors and macroeconomic factors on Islamic bank profitability in Malaysia,. Although there has been numerous studies which investigated the determinants of profitability of Islamic and conventional banks, the focus of this study is to determine the exact variable used in practice by Islamic banks in Malaysia and to what extent is the difference in terms of the determinants between Islamic and conventional banks. There are growing studies examining the determinants of profit margin and profitability of Islamic banks in many countries around the world. Most of the studies have divided the bank determinants into certain categories, such as (1) external factors, i.e. bank size, capital adequacy, credit risk, management efficiency and business mix, (2) external factors, i.e. bank concentration, and (3) macroeconomic factors, i.e. inflation and economic growth. The literature on spreads consists of studies on determination of profit margin as well as financing rate spread.

The most prominent theoretical model of determination of interest margin is the bank dealership model by Ho and Saunders (1981), whereby the size of bank interest margin is explained based on deposit and loan situations, hedging behaviour, and expected profit maximisation. According to the Dealership Model, banks are assumed to be risk-averse in their role as financial intermediaries. This model is based on the uncertainty faced by banks, whereby banks receive deposits at random times as compared to giving out loans to customers in a stochastic manner. Therefore, this uncertainty of receiving deposits and giving out loans implies that banks face an inventory risk, which has to be compensated by a spread between loan and deposit rates, which is the pure financing spread. In this regard, there are criticisms of the Ho and Saunders Dealership Model. Some researchers, for instance, McShane and Sharpe (1984) countered that banks face uncertainty in the short-term money market interest rate as opposed to the deposit and loan interest rates. Banks acting as intermediaries, will maximise profit as well as may adopt a risk aversion approach. Banks need to consider the fees charged by the market and volatility of the market rate in applying the profit margin to their customers. In a study by Lerner (1981), it was argued that the model of bank margins should consider elements of the bank's operations such as administration cost to maintain loan and deposit contracts and the institutional structure of the banking market. According to studies by Wong (1997), Daniel et al. (2012) and Nicolae et al. (2015), they found that in general, the larger the riskaverse practised by banks, the larger the spread imposed by banks. However, the approaches in determining bank margins generally depends on certain aspects 
such internal and external factors faced by banks. There are numerous studies regarding bank margins across the globe, which have shown a similar pattern of bank margin determinants being practised in their pricing structure.

For Islamic banking, the approach in determining bank margins is generally similar with conventional banking (focus group interviews). However, the dealership framework established by Ho and Saunders (1981) is used by researchers worldwide. This model served as the basis for frameworks and it has been adapted in different research contexts. For example, a study conducted by Erwin and Rahmatina (2010) on Indonesian Islamic banks, showed that bank margins were determined by pure spread, i.e. interest volatility and default risk, and other factors such as liquidity risk, capital base, implicit returns to depositors, opportunity cost and management quality. Thus, the determinants of bank margins involved are dependent on research context and purpose, and, are quite similar for most banks. Samy and Mohamed (2008), conducted a study using the dealership model in measuring Islamic bank margin determinants in Tunisia. Based on empirical analysis, three categories were identified, i.e. internal factors (capital ratio, overheads, bank loans, liquidity ratio, and noninterest bearing assets), external factors (growth and inflation), and financial market (financial structure and market concentration). The results obtained conformed to the literature, i.e. bank loans significantly reflected that banks were interest paying, and therefore this contributed to increase in net interest margins. High net interest margins tend to be associated with banks that hold a relatively large amount of capital and overheads. Size was found to impact negatively on profitability. On the other hand, macroeconomics (growth and inflation) had no impact on bank profitability. With regards to financial structure, stock market development had a positive impact on bank profitability. A study conducted by Fernando and Angelo (2015) in Brazil was also based on the HoSaunders dealership model. The study was conducted to measure bank spread in Brazilian banks. The study introduced two categories, i.e. (1) individual bank characteristics with three determinants, i.e. administrative cost, revenue from service and coverage ratio, and (2) macroeconomics, i.e. the real GDP growth (Herfindahl-Hirschman Index - HHI). Generally, the results also conformed to the literature.

\subsection{Definition of Bank Margin}

Bank margin is generally defined as the spread between interest revenue on bank assets and interest expense on bank liabilities, which is presented as a proportion of the average bank assets or earning assets (Ho \& Saunders, 1981; Erwin \& Rahmatina, 2010). Bank margin has been postulated to determine a bank's performance, as profit reflects the bank's performance. The following are the commonly practised factors that are used in the pricing of Islamic bank financing products extracted from literature: 


\subsubsection{Liquidity risk}

This is computed as the ratio of a bank's liquid assets to total assets. The degree to which banks are exposed to liquidity risk varies across banks. A bank with higher liquidity faces lower liquidity risk hence is likely to be associated with lower spreads due to a lower liquidity premium charged on loans. Banks with higher risk tend to borrow emergency funds at high cost and thus, charge liquidity premium leading to a higher spread (Maureen \& Joseph, 2014). Similar results were obtained from research conducted by Erwin and Rahmatina (2010) in Indonesia regarding the comparison of bank determinants between Islamic banks and conventional banks. The results showed that when liquidity risk was higher, bank margins were also higher.

\subsubsection{Credit risk}

The non-performing loans to total loans is used as an indicator of credit risk assessment. Result from a study by Daniel et al. (2012), showed that an increase in provision for loan losses implied a higher cost of bad debt write-offs. Given the risk-averse behaviour, banks facing higher credit risk were likely to pass the risk premium to the borrower, leading to a higher spread. Hence the higher the risk, the higher the price of financing to compensate for the likely loss. Likewise, research by Nicolae et al. (2015) also confirmed that bank margins paralleled credit risks, therefore a higher credit risk would result in a higher bank margin.

\subsubsection{Default risk}

Default risk is the risk of non repayment on financing due to the inability of the fund user to fulfil obligations to the bank. Both Islamic and conventional banks have to face this risk in their banking operations. Since, financing is the major source of income, the deterioration of financing quality will affect bank profitability and subsequently bank viability. As default risk increases, Islamic banks will also have to increase the default risk premium charged to customers. Results on empirical testing from a study by Erwin and Rahmatina (2010) indicated that Islamic bank margins responded positively to default risks, the higher the default, the higher the premium based on individual credit scoring, likewise, higher bank margins.

\subsubsection{Capital adequacy ratio}

Capital ratio is a valuable tool for assessing the safety and soundness of banks. Some researchers explained that when a bank had high capital ratio or more equity capital, it showed that the bank was more safe and an advantage to secure 
higher profitability (Nicolae et al., 2015). Based on their statistical research, the result proved that capital positively affected profitability. This result was consistent with Panayiotis et al. (2008) who also found a positive relationship between capital and profitability. Abreu and Mendes proposed in their study that a well capitalised bank faced lower expected bankruptcy costs and showed profit later. A study by Abduh and Yameen (2013) also found the same result with a measure of capital by using equity to total asset ratio for Islamic banks. However, Wasiuzzaman and Hanimas (2010) found that there was a negative relationship between capital and Islamic bank profitability in Malaysia.

\subsubsection{Non interest bearing assets}

This measure will effectively capture all sources of non-interest income generated by diversified banks. The higher the ratio, the greater the focus on non-traditional banking activities. Research by Oliver et al. (2015) showed that past developments in banking was described as disintermediation, i.e. a shift from traditional financial intermediation to other banking activities in order to compensate for declining profitability. Result showed that with non-interest income, the lower corresponding fees charged, resulted in a decrease in net interest margin (NIM).

\subsubsection{Implicit returns to depositors}

Implicit payments reflect extra payments to depositors through service charge remission which arise from competition in the market for deposits. These extra payments should reflect higher margins. A study made by Erwin and Rahmatina (2010) showed that implicit returns to depositors corresponded positively to bank margins which explained that whenever implicit returns to depositors increased, bank margins increased accordingly.

\subsubsection{Operating expenses}

Operating expenses also appears to be one of the important determinants of bank profitability. A poor expenses management contributes to poor profitability, whilst an efficient expenses management raises a bank's profit. A bank's expenses include the total amount of wages and salaries and costs of running branch office facilities. Operating expenses indicators are expected to be negatively related to profitability as lower operational costs may help to increase bank profit. Panayiotis et al. (2008) found a negative and statistically significant relationship on expenses with the proxies of cost to income ratio and operating expenses to total assets. However, some studies suggested that the positive relationship of expenses and profitability was due to higher payroll expenditures which could 
contribute to the requirement for more productive human capital. Oliver et al. (2015) and Joaquin and Juan Hernand (2004) found that expenses positively affect bank profitability. The study indicated that higher expenses or operating costs could generate higher profit for banks. As mentioned earlier, in accordance with the efficiency wage theory, it was stated that the productivity of employees increased proportionally with wage rates,. Izahar and Asutay (2007) asserted an insignificant and positive relationship with profitability indicators in their study on Islamic banks and suggested that the more profitable the bank, the higher the salary expenses.

\subsubsection{Management efficiency}

Management efficiency is a reflection of the ability of management to minimise costs at a given level of income or to maximise income at a reasonable cost. Research by Erwin and Rahmatina (2010) indicated that a more efficient management would be able to reduce costs and thus, a bank will be able to charge a lower margin to attract customers. Results by Joaquin and Juan Hernand (2004) concurred with the earlier study that management efficiency had a negative impact on bank margins, because when cost is reduced due to management efficiency, the bank will charge a lower margin.

\subsubsection{Bank size}

Bank size is one of the variables to determine bank profitability. According to research by Abduh and Yameen (2013) and Maureen and Joseph (2014), they found that bank size is a very strong variable that will positively influence the level of profitability. Abduh and Yameen (2013) asserted that a larger bank would have an advantage in negotiating price of input, and can reduce the bank's average cost. Therefore, the bank is able to enjoy economies of scale and improve its profitability. However, Wasiuzzaman and Hanimas (2010) and Panayiotis et al. (2008) found that the size of Islamic banks is insignificant and it is not significant enough to affect bank profitability. Wasiuzzaman and Hanimas (2010) discovered that bank size correlated highly with capital ratio and concluded that the profitability of Islamic banks in Malaysia is not influenced by bank size.

\subsubsection{Gross domestic product (GDP)}

Gross Domestic Product (GDP) is a measurement of total economic activity within an economy. It is considered as an external determinant of bank profitability given the positive relationship between growth of the economy and well-being of the banking sector (Oliver et al., 2015). Many have studied the effect of economic growth on bank profitability. For instance, a study in Kenya by 
Daniel et al. (2012) found that there was a positive association between banking sector performance and economic growth. This further confirmed the findings by Nicolae et al. (2015) in which macroeconomic conditions such as economic growth was statistically significant and positively related to bank margins as attested by 27 banking systems in the European Union (EU). Wasiuzzaman and Hanimas (2010) also found a positive relationship in that high economic growth led to improvement in credit quality and thus increased bank profitability.

\subsubsection{Competition}

Unemployment rate was still considered high during the economic recovery after the 2007-2008 world financial crisis. In order to survive in the competitive world then, banks needed to upgrade themselves to attract customers and also to earn a higher profit. This indicated that competition at the time was high, especially in the banking industries. Rasiah (2010) found that the increasing competition was actually caused by the deregulation of the banking industry where new financial institutions could enter the fray. Studies have been conducted on the effect of competition on bank profitability and they showed differing results (Nicholas, 2011; Alhasan \& Ohene-Asare, 2016). Theoretically, competition will reduce the profit of a bank as profit is shared when competitors increase. The Islamic banks in Malaysia need to compete with other Islamic banks including conventional banks, while conventional banks have to compete only with Islamic banks. For example, a study conducted in Malaysia by Haron (2004), showed that the result was not significant. Although it was not significant, there was strong evidence which showed that corporate and shareholder wealth were maximised in a monopolistic market. Haron (1996) also found that Islamic banks brought more benefit (robustness to external shocks, fairness and social justice) to depositors compared to conventional banks. Likewise, there was a negative and insignificant relationship between competition and bank operations (Bashir, 2003). Nevertheless, Demirguc-Kunt and Huizinga (2001) found that competition had a negative and significant impact on bank performance. The result indicated that bank profit was reduced due to stronger competition. Besides that, Bashir (2003) also found that competition resulted in a negative impact on bank performance in their study. In their study, a number of banks were used to represent the competition in order to determine the impact of competition on the profit of Islamic banks. The result showed that there was a negative but insignificant impact on bank profitability except for net non-interest margin. A study by Alhasan and Ohene-Asare (2016), suggested that competition exerted a positive influence on efficiency. Improved competitiveness in the banking industry would translate into lower interest rate spread (lower profit). However, this will, ultimately improve access to bank credit and impact positively on the banking sector, specifically and economic growth, generally. 


\section{Methodology}

A qualitative research approach was applied in this research. According to John (2007), qualitative research allows researchers to understand how they construct their worlds and meaning they attribute to their experiences. The choice of qualitative research methodology can be further explained by its ability to generate comprehensive information to determine the pricing practices conducted by Islamic banks as brief answers to structured questions is insufficient to provide the required in depth information to assess Islamic bank financing practices adequately (Sekaran, 2003). This research had engaged a focus group exercise, This focus group was developed specifically to gather insights, opinions and actual statements of experts in Islamic banking. The intention of the focus group was to validate and explore new items of determinants obtained from literature. The focus group interview was to clarify which department managed risk practices, the policies which guided pricing practices, the overall objectives of price setting and to identify the exact determinant(s) and also to explore new possible determinants of bank margins.

\subsection{Sample and Data Collection}

According to Babbie (2013) and Sekaran (2003) it is appropriate to have between five to 10 people in a group to get a fair opinion. The parties involved in the focus group interviews were the head of risk management of Bank Muamalat Berhad and Chief Executive Officer (CEO) of CIMB Islamic Bank Berhad, Special Advisor and also Chief Financial Officer (CFO) of Bank Islam Malaysia Berhad and Chief Financial Officer (CFO) of Maybank Islamic Berhad. All interviews were conducted between January and September 2016. The focus group interviews involved three phases: data collection, discussion, findings, and conclusion. The objective of data collection was to obtain a rich set of information regarding bank margins and pricing practices. Data collection began with a focus group discussion, involving all senior Islamic bank officers who had vast experiences in risk management. Questions used in the focus group exercise were as follows:

1. What are the policies which guide pricing practices?

2. Which department handles pricing practices?

3. What is the pricing practices of Islamic banks?

4. What is the overall objective of a bank in determining price setting?

5. What determines price setting?

The respondents were requested to give their opinion on issues related to price structure, pricing practices and bank margin determinants. The discussion was recorded, and then transcribed verbatim. At the same time, detailed notes were taken to ensure that data and information especially technical terms were 
noted correctly. Permission was obtained from respondents to contact them again should further clarification or additional questions arise during the transcription. The meeting with heads of risk management of Islamic banks was conducted to understand issues regarding bank margins and pricing practices. The risk department plays an advisory cum enforcement role regarding risk management and also facilitates other departments especially the treasury department to formulate pricing as practised by Islamic banks. Initial contact was made with all respondents to determine a suitable time for interviews.

The focus group exercise was conducted on dates decided earlier based on mutual consent. The exercise was held at the bank premises and conducted within an hour. This research employed the verbal protocol method to conduct in depth interviews with respondents. Verbal protocol is a diagnostic tool (Payne, 1994; Berne, 2004) which is useful particularly when a research is exploratory (Kuusela \& Paul, 2000). The verbal text retrieved from interviews was then segmented based on themes and coded with a pre-defined coding scheme. The coding scheme was developed from existing literature (Patrick \& James, 2004; Ho \& Saunders, 1981) and bank margin determinants (Hameed, 2003; Erwin \& Rahmatina, 2010). The data were analysed by comparing bank margin determinants from literature (Hameed, 2003; Erwin \& Rahmatina, 2010; Nicolae et al., 2015; Abduh \& Yameen, 2013) with themes that emerged from the coding stage.

\section{Findings}

The recorded interviews were reviewed several times before being transcribed. Subsequently, a phenomenological approach to analyse data was adopted, which involved interpreting and reflecting on the data transcript so as to achieve a holistic understanding of the meaning of the participants' experiences (Othman, 2015). Furthermore, the area of bank margins and its determinants had been thoroughly discussed by various researchers. Hence, this data analysis approach was chosen to allow Islamic bank experts to express their opinion based on their own experiences. Respondents expressed their thoughts about pricing practices and generally they corresponded with what was found in the literature. There were three main categories of bank determinants as suggested from literature, i.e. bank specific characteristics, industry specific indicators and macroeconomic indicators. Results from the focus group interviews had shown certain themes in policies that guided pricing practices, the department(s) involved, pricing practices, the overall objective of profit margins and price determinants as indicated by statements reiterated by respondents during the interview process. All discussions were based on selected text transcripts acquired from focus group interviews in the findings and discussion section. The discussion on bank determinants in price setting will be elaborated in Table 1 as follows. Discussions on the above intentions are based on four Islamic banks in Malaysia, i.e. Bank Muamalat Malaysia Berhad, CIMB Islamic Berhad, Bank Islam Malaysia Berhad and Maybank Islamic Berhad. 


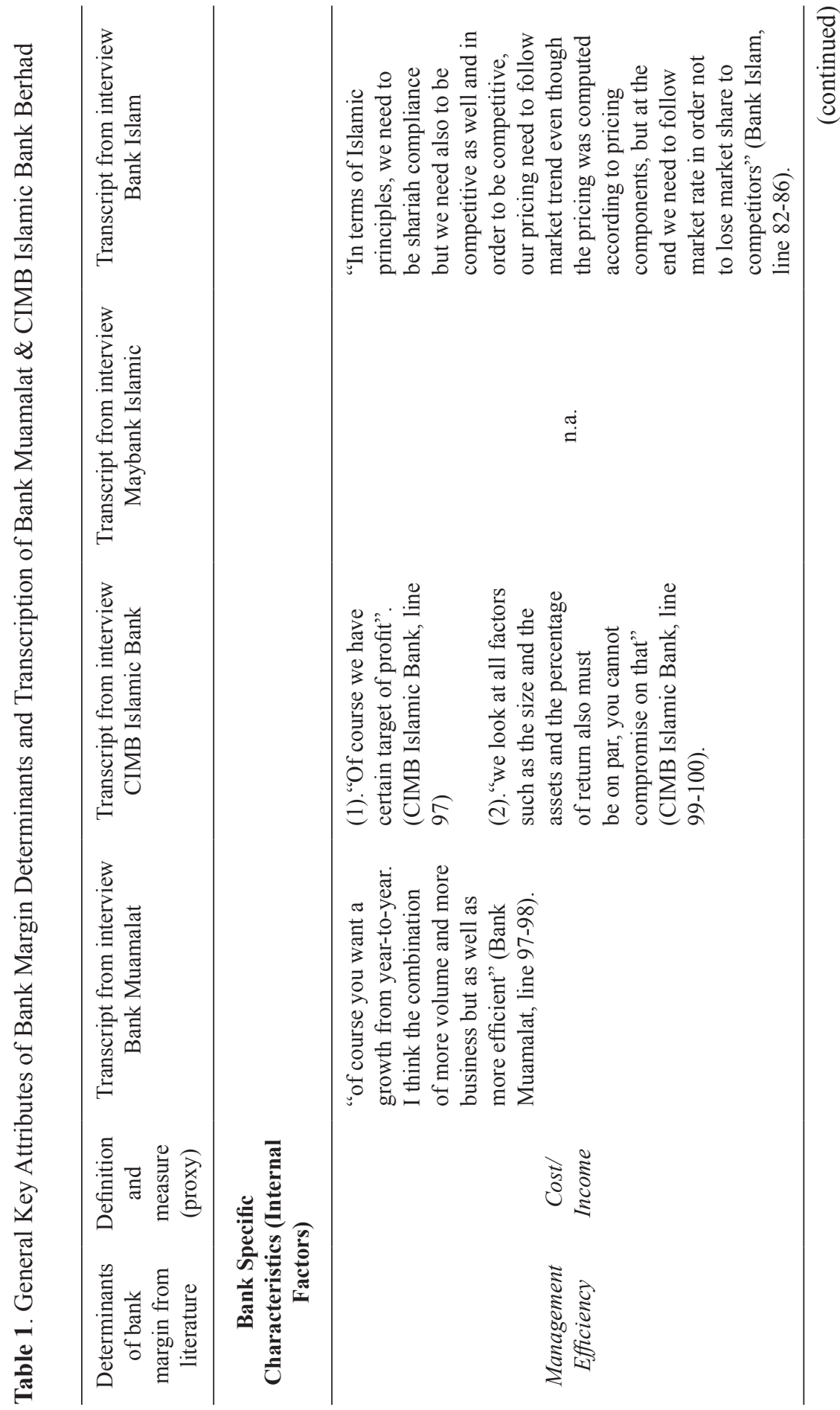




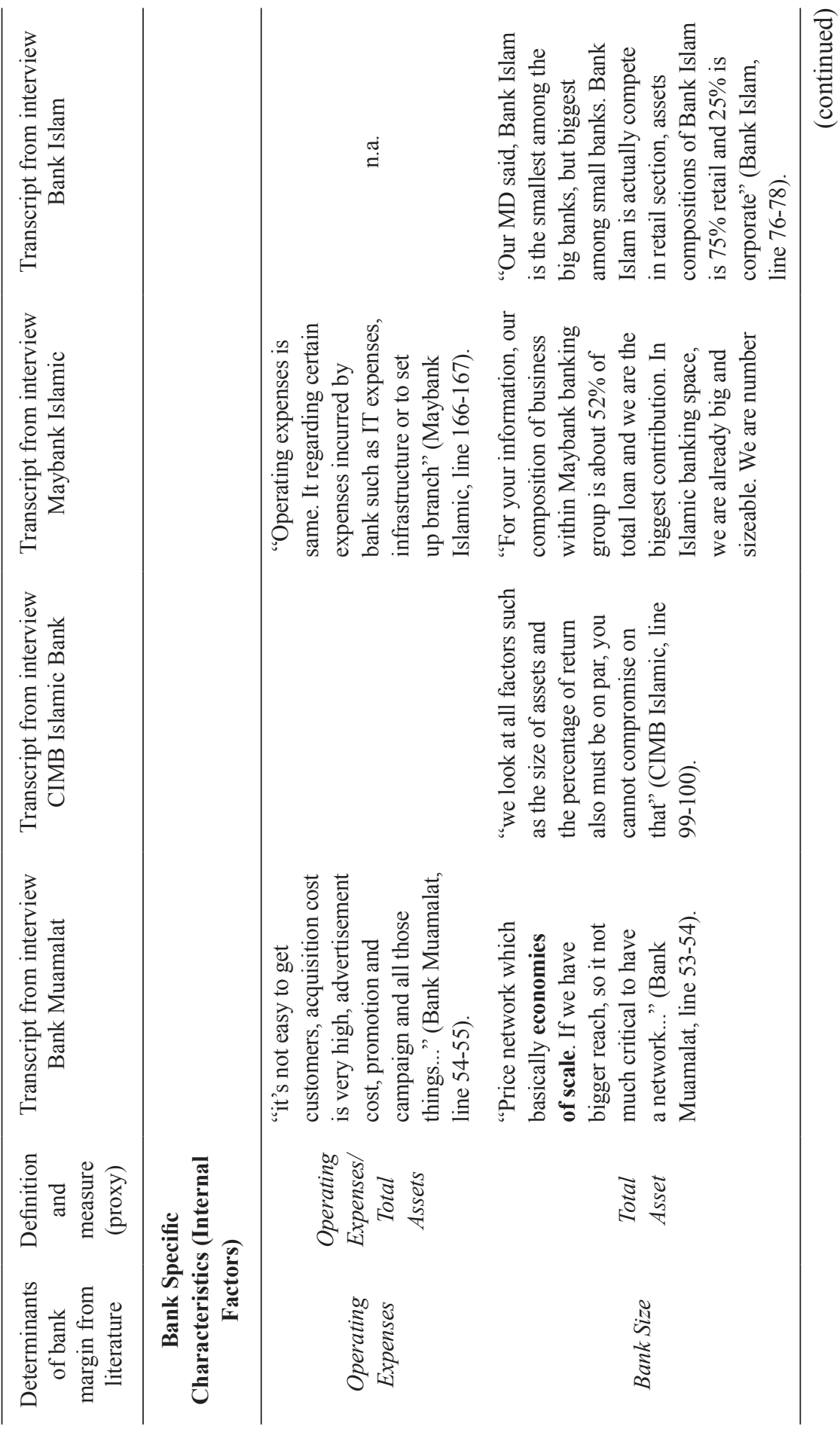




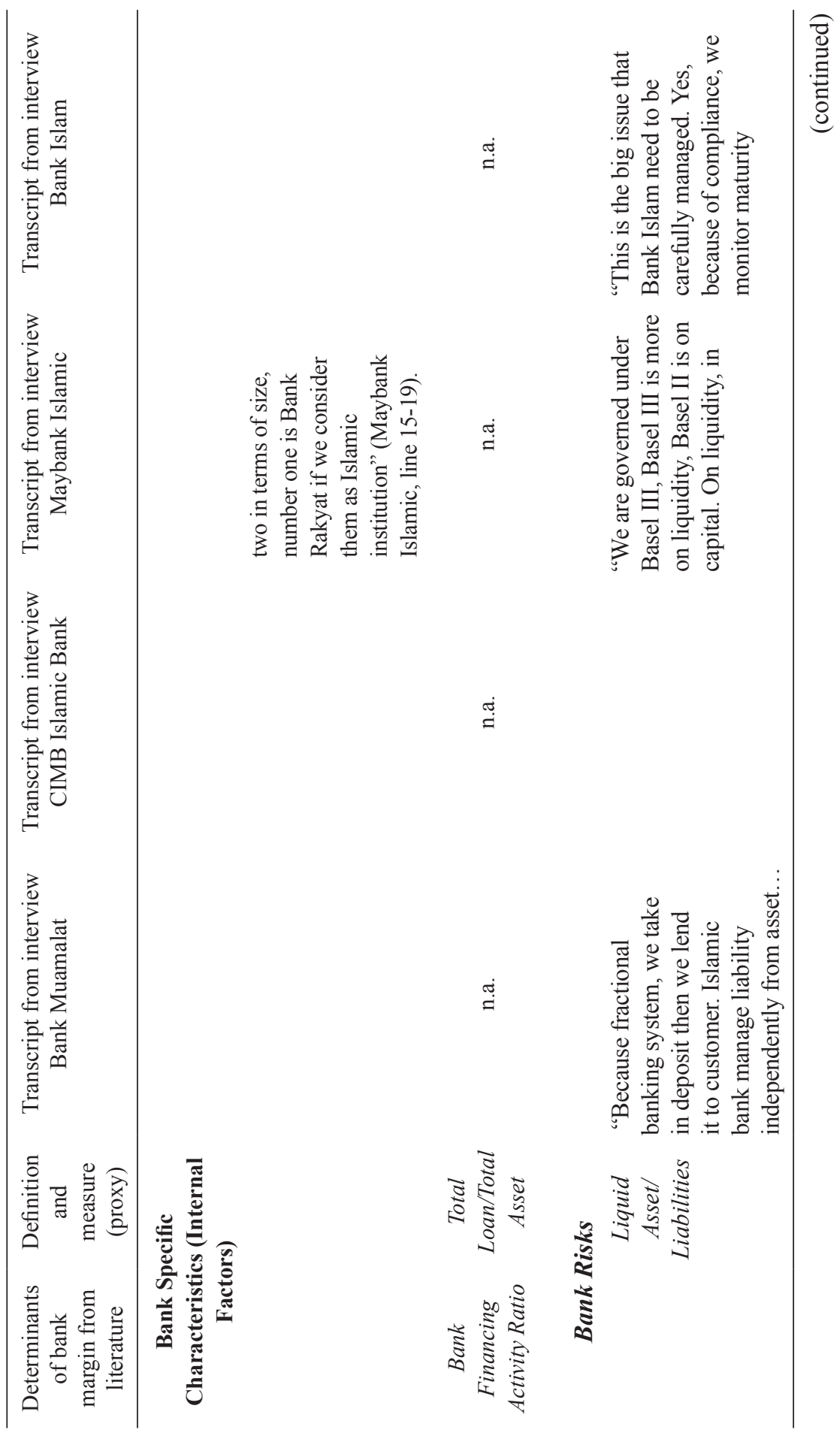




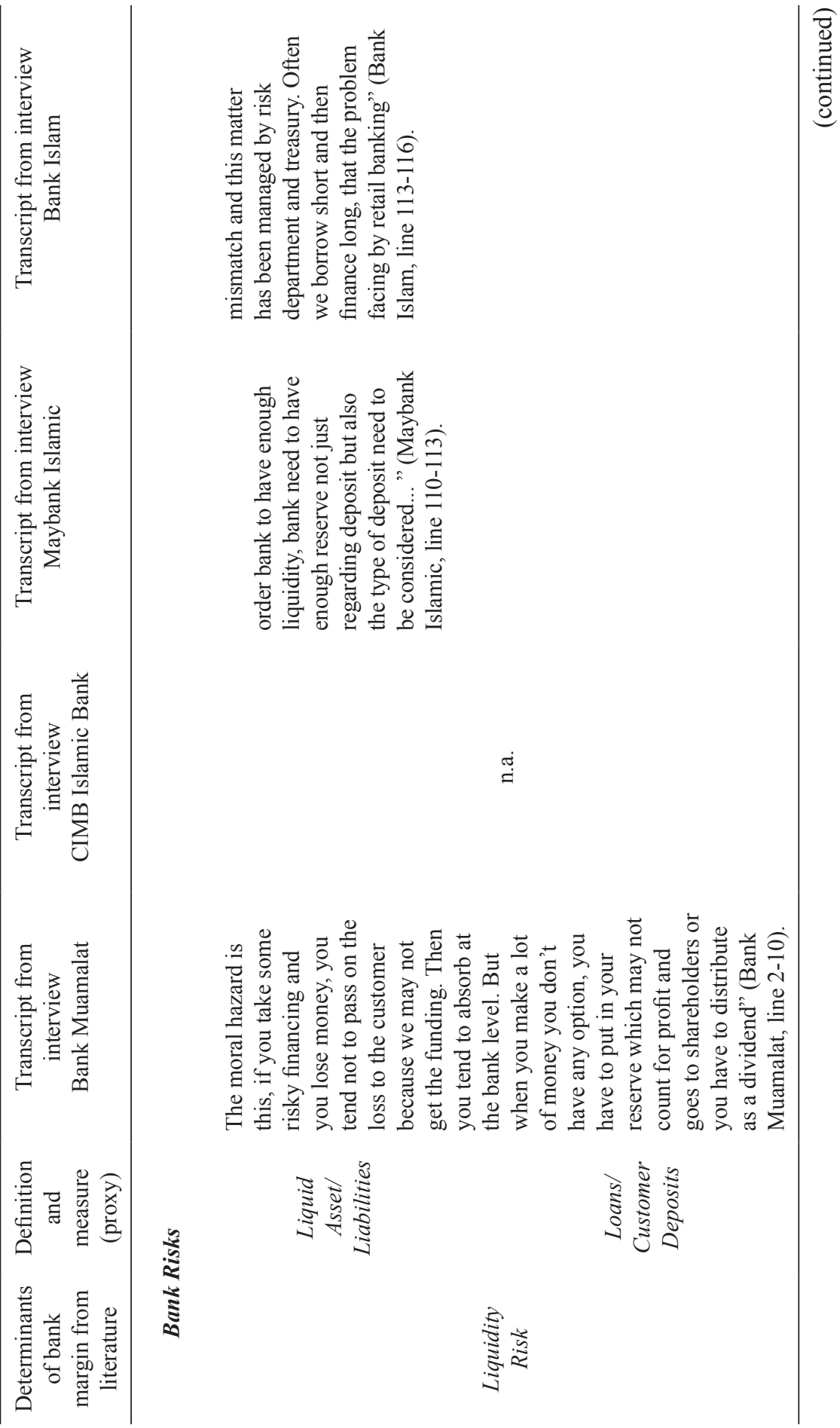




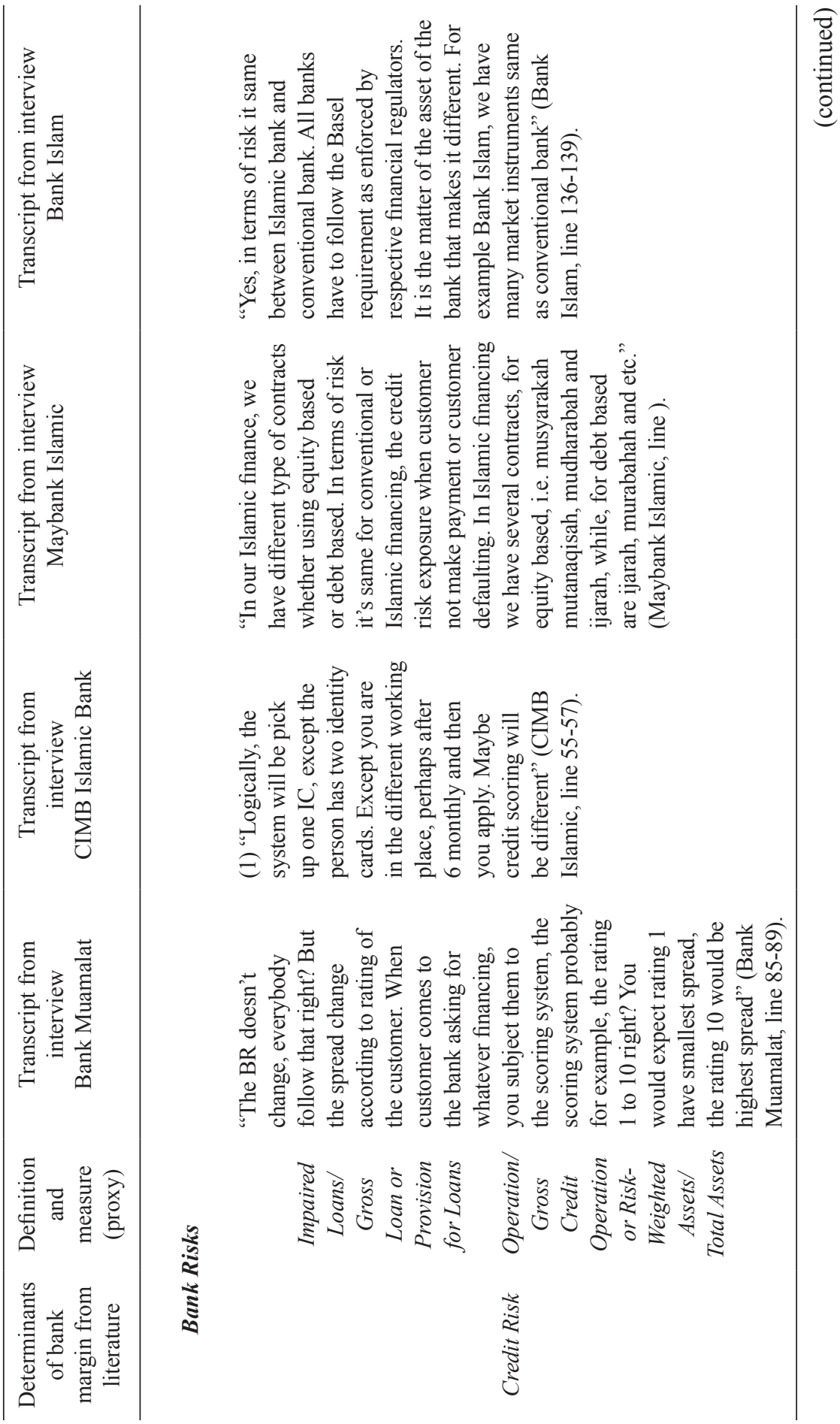




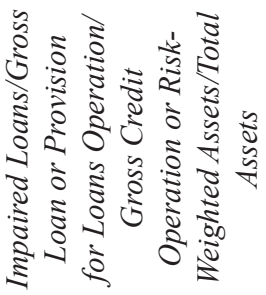

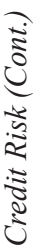




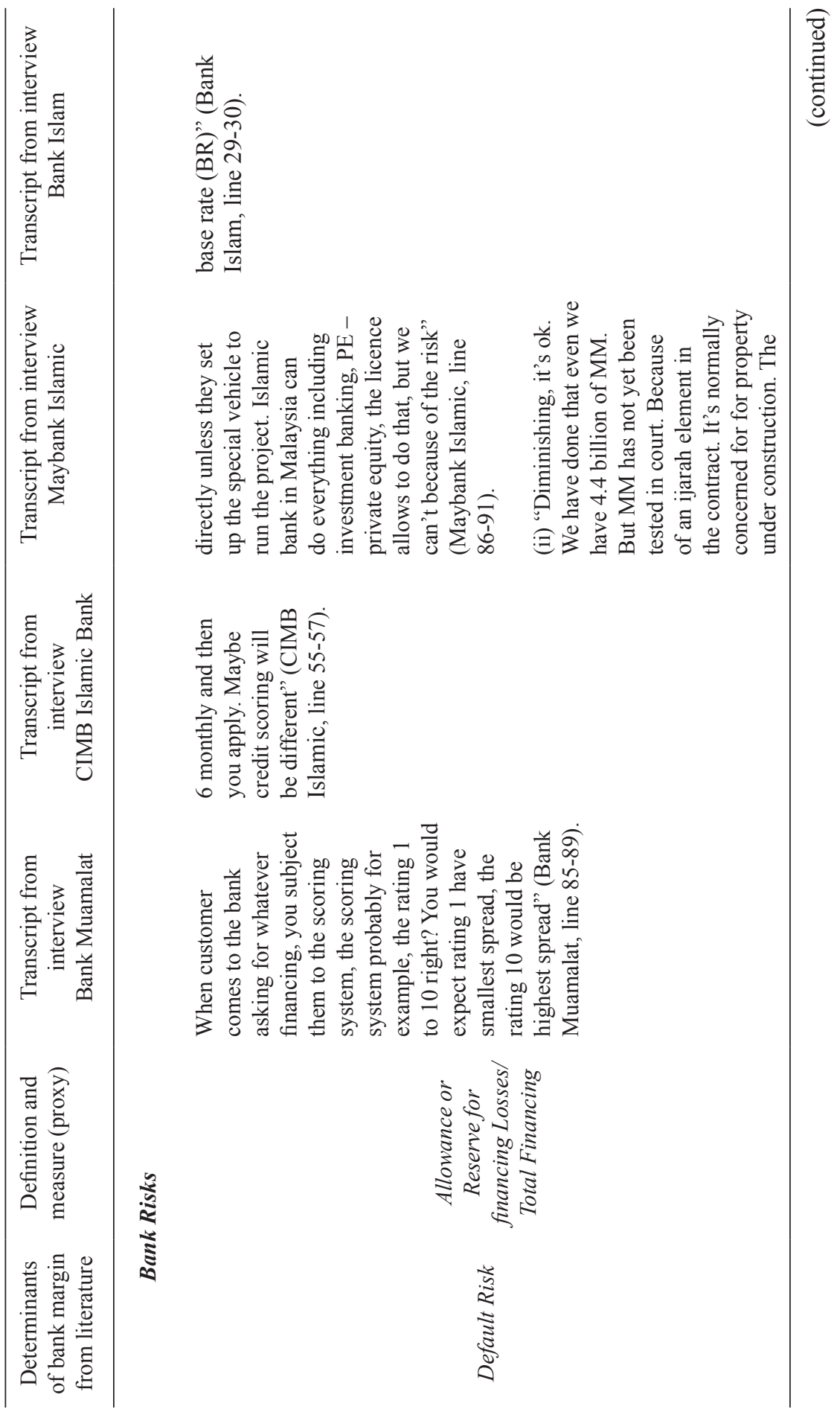




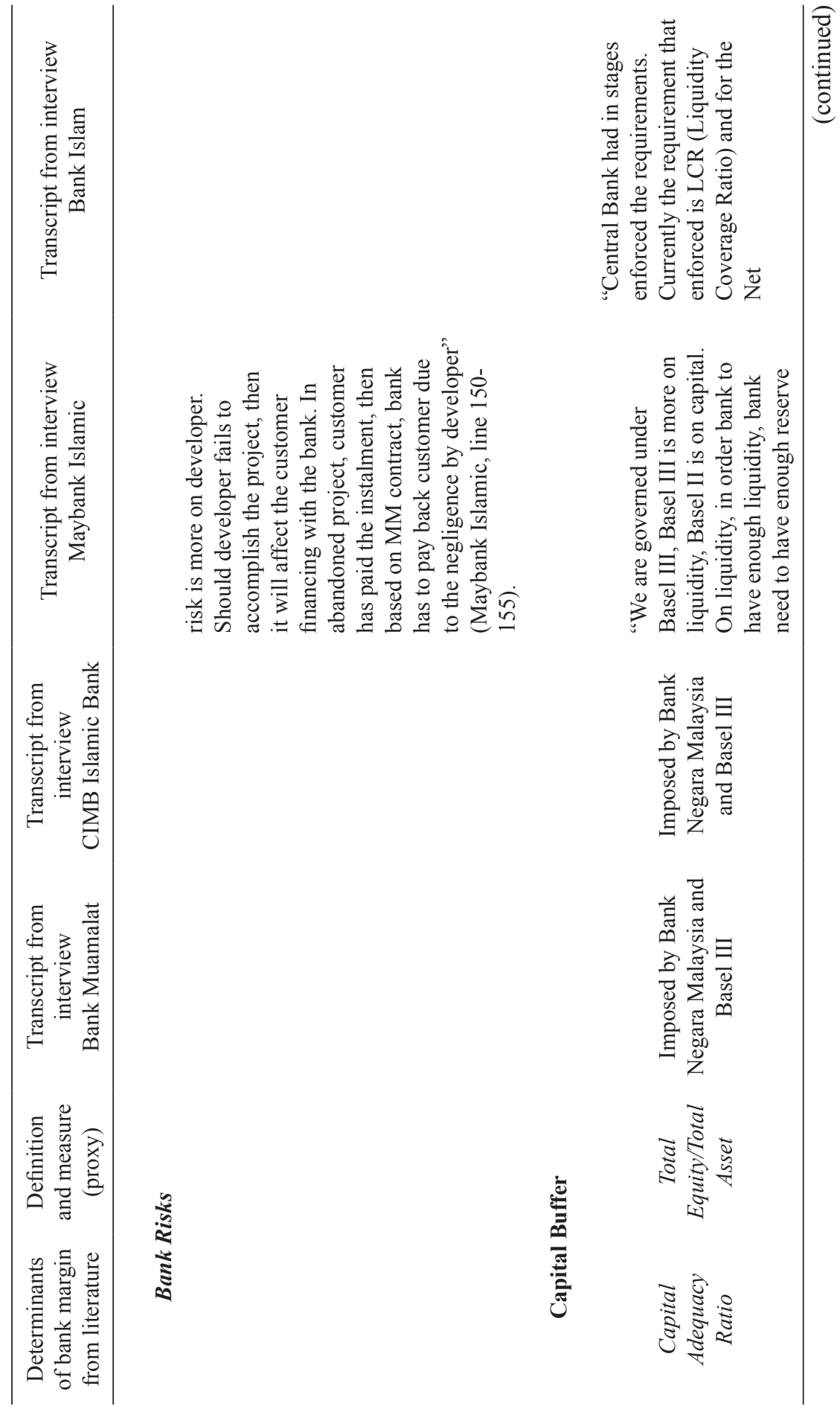




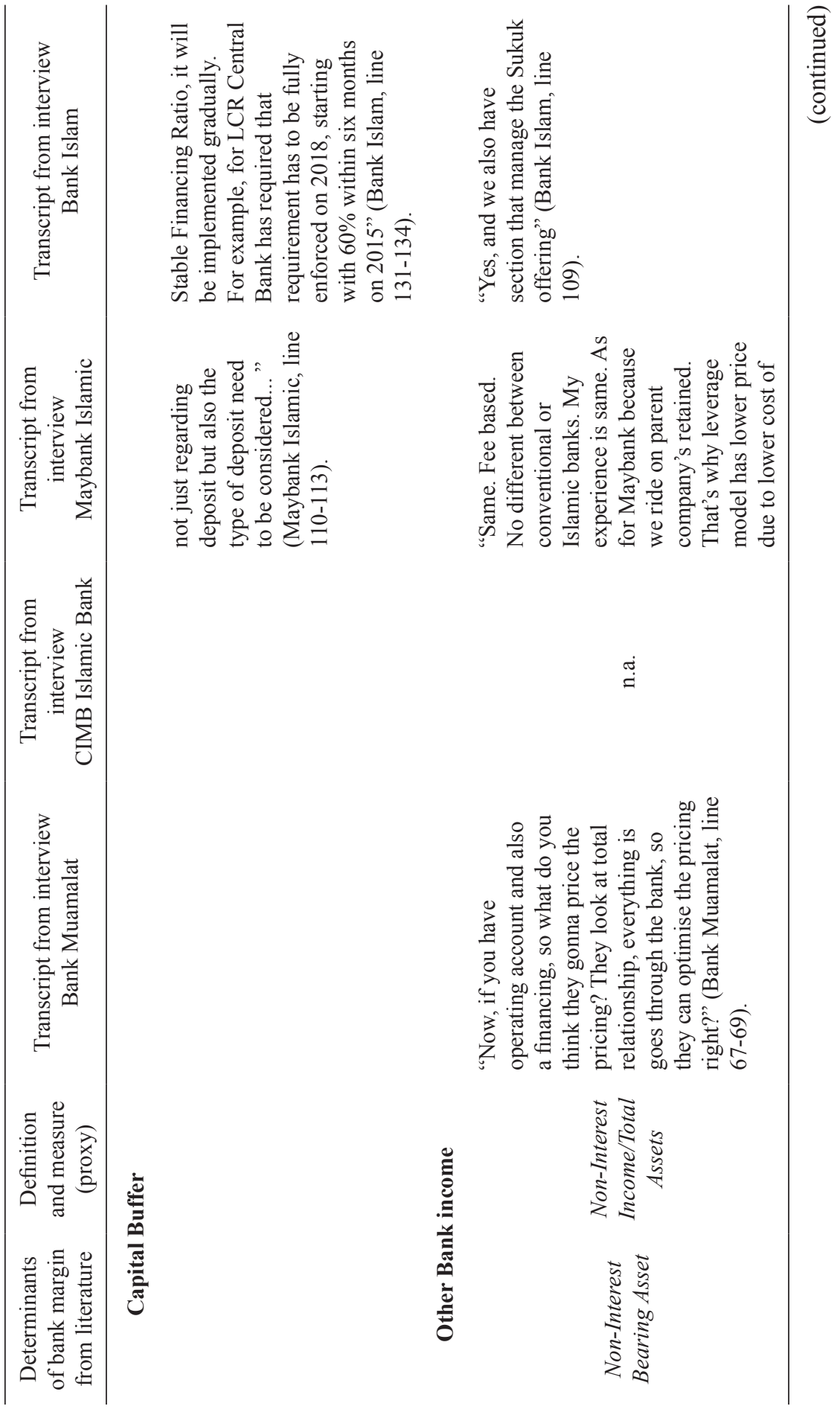




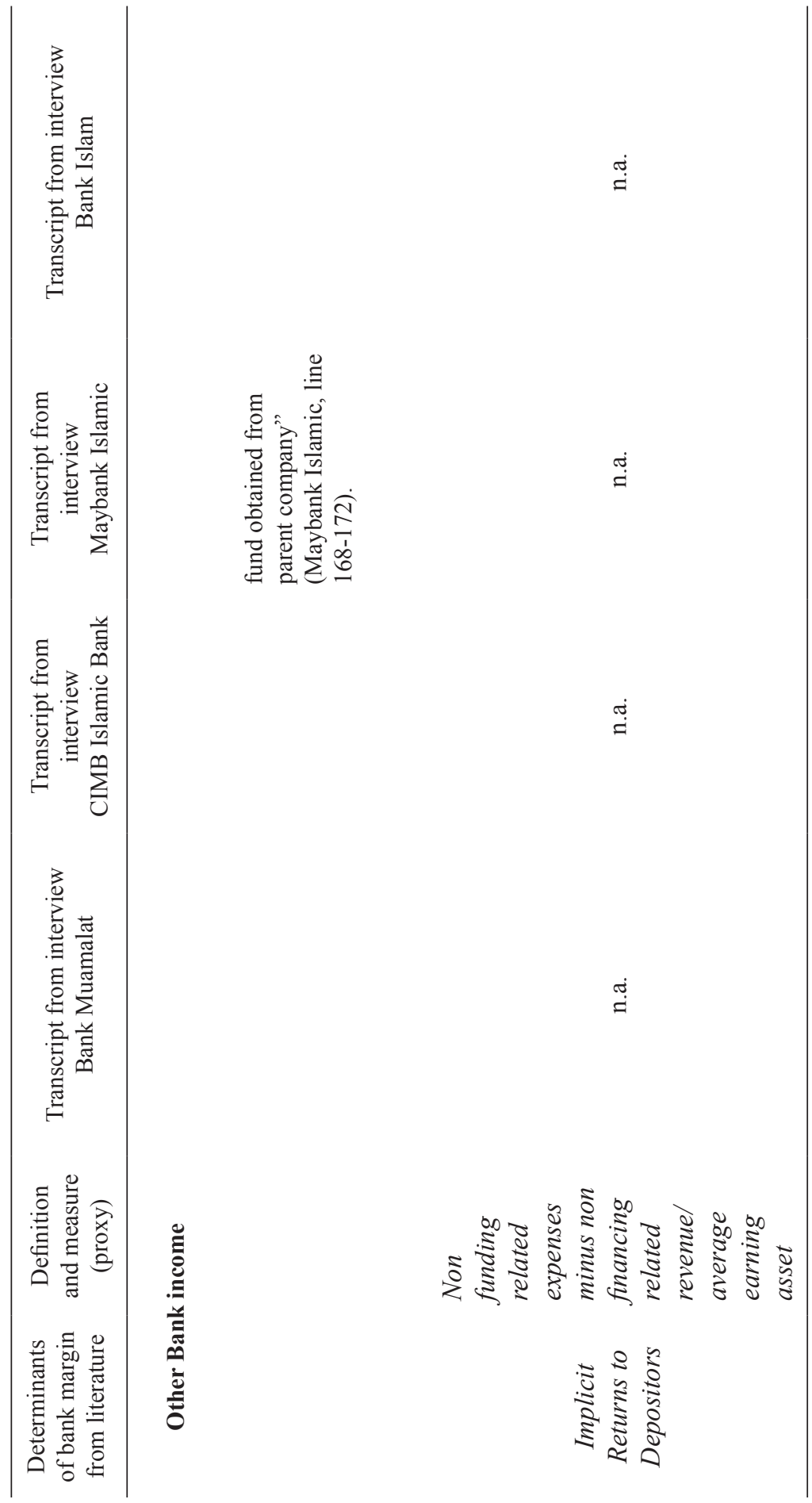

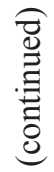




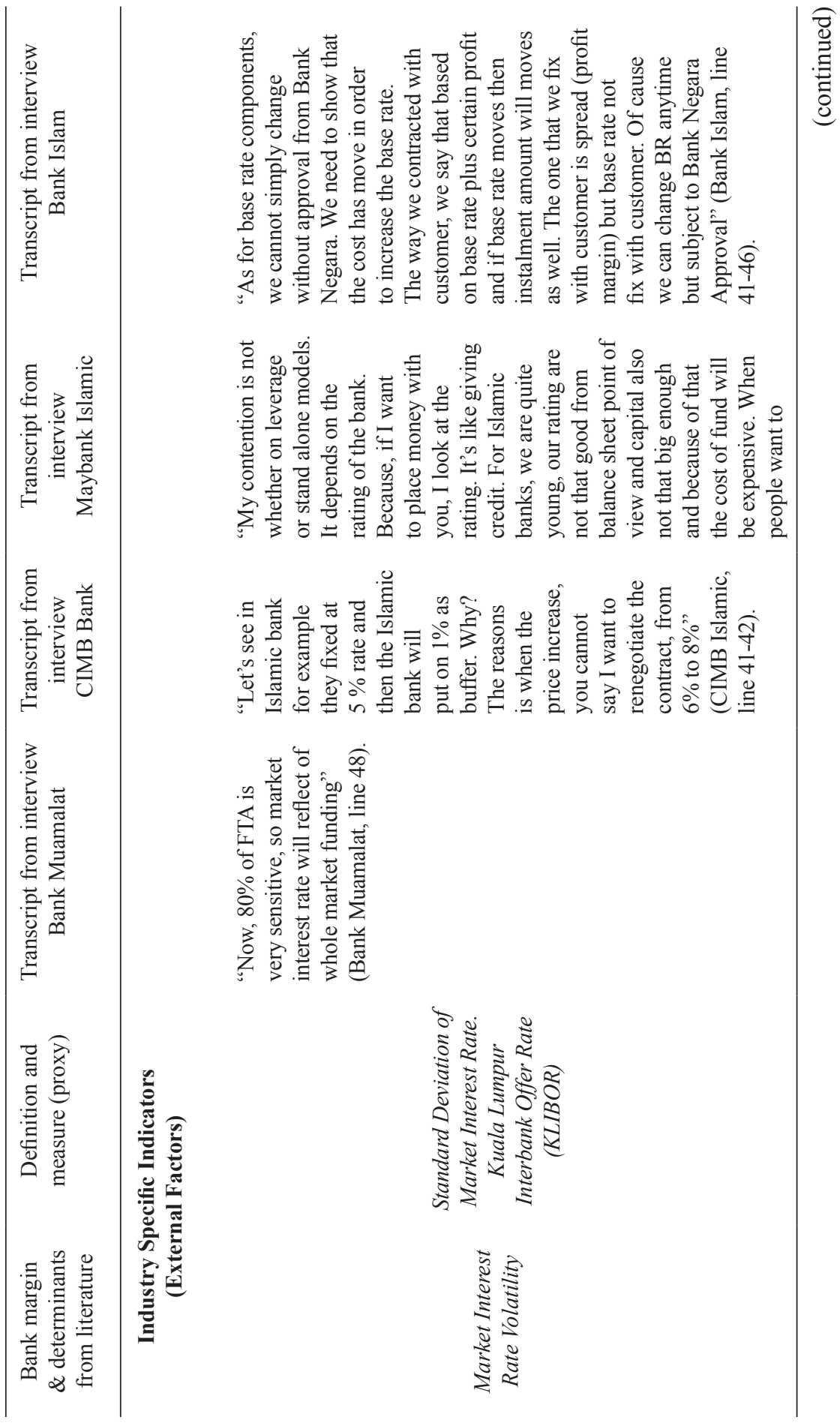




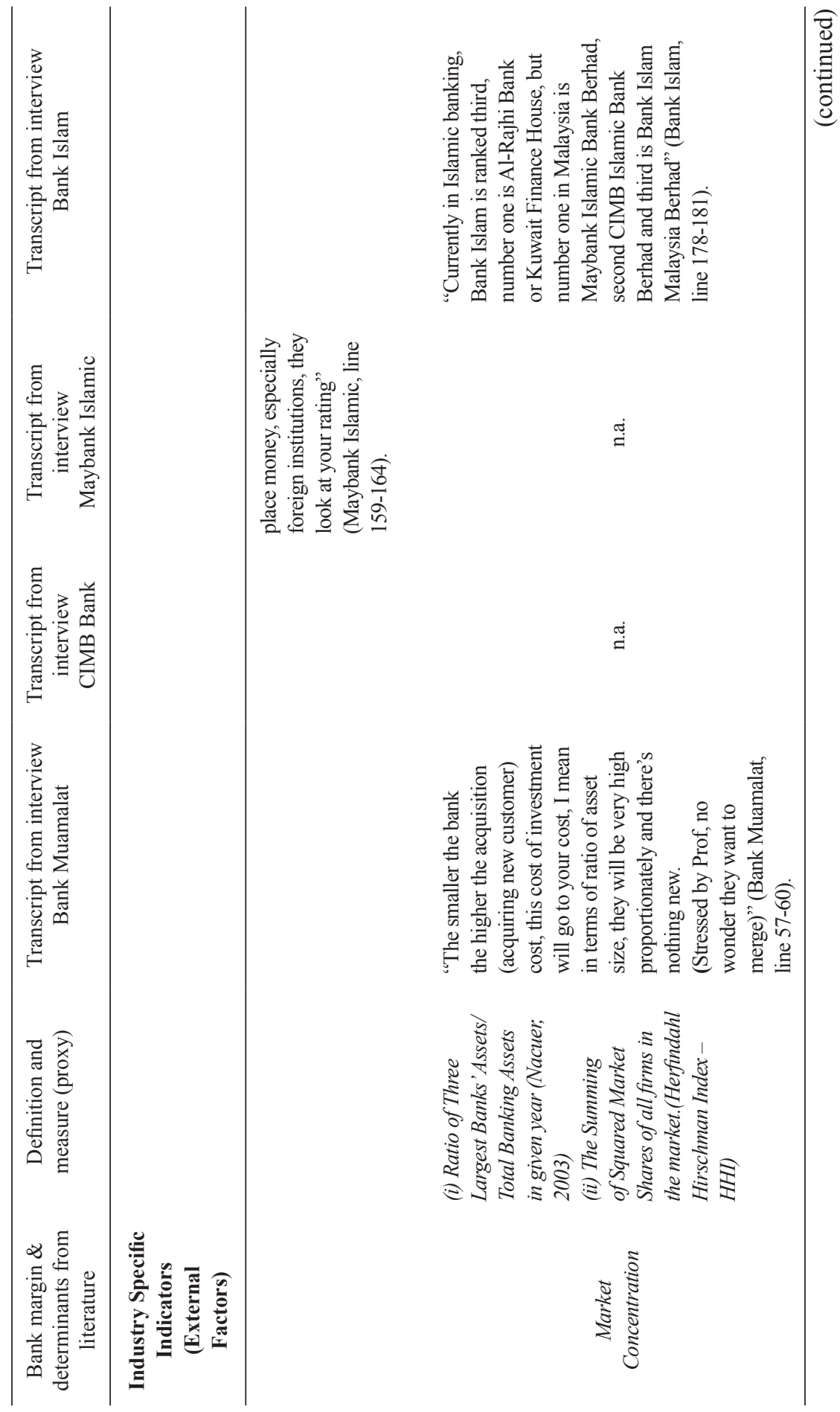




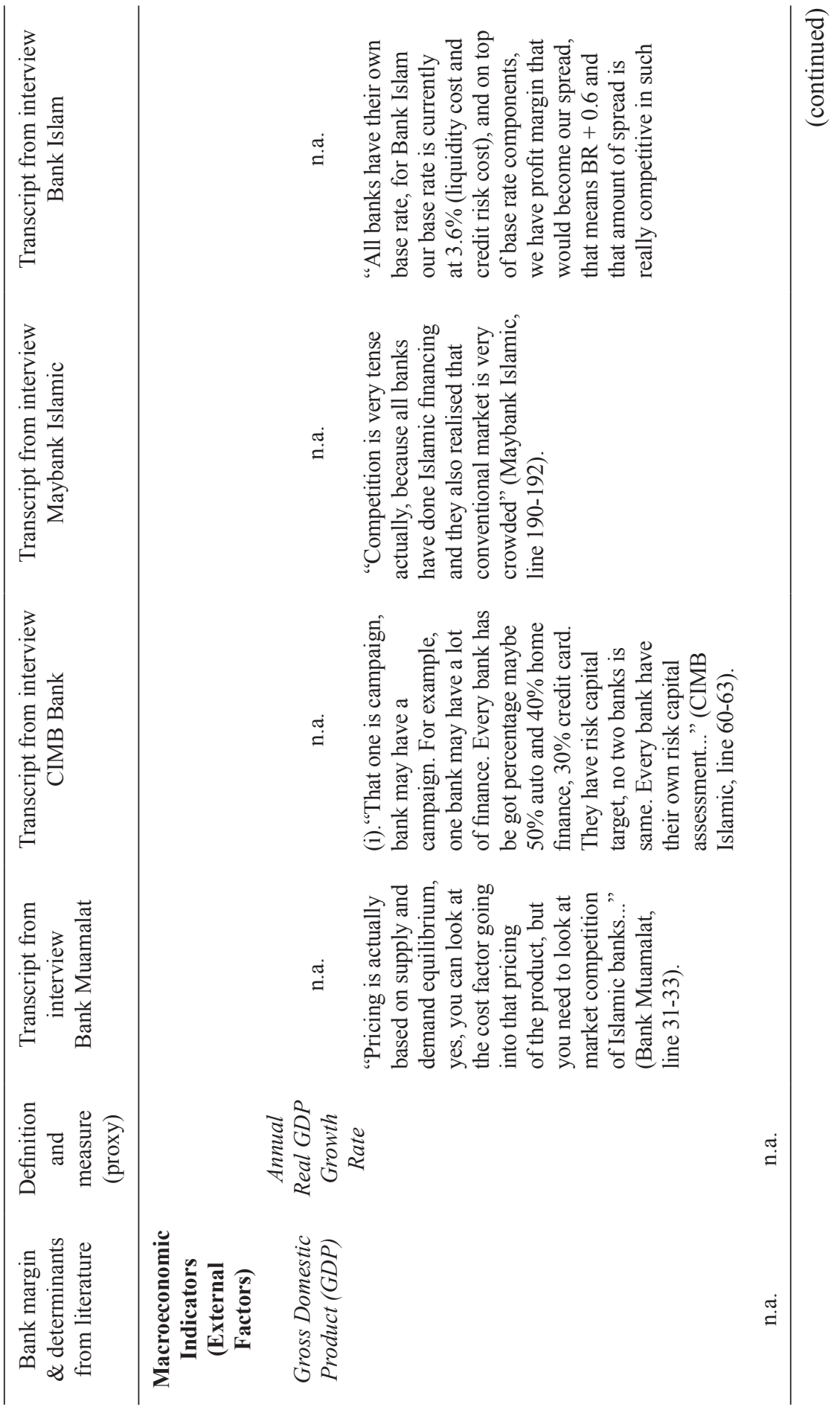




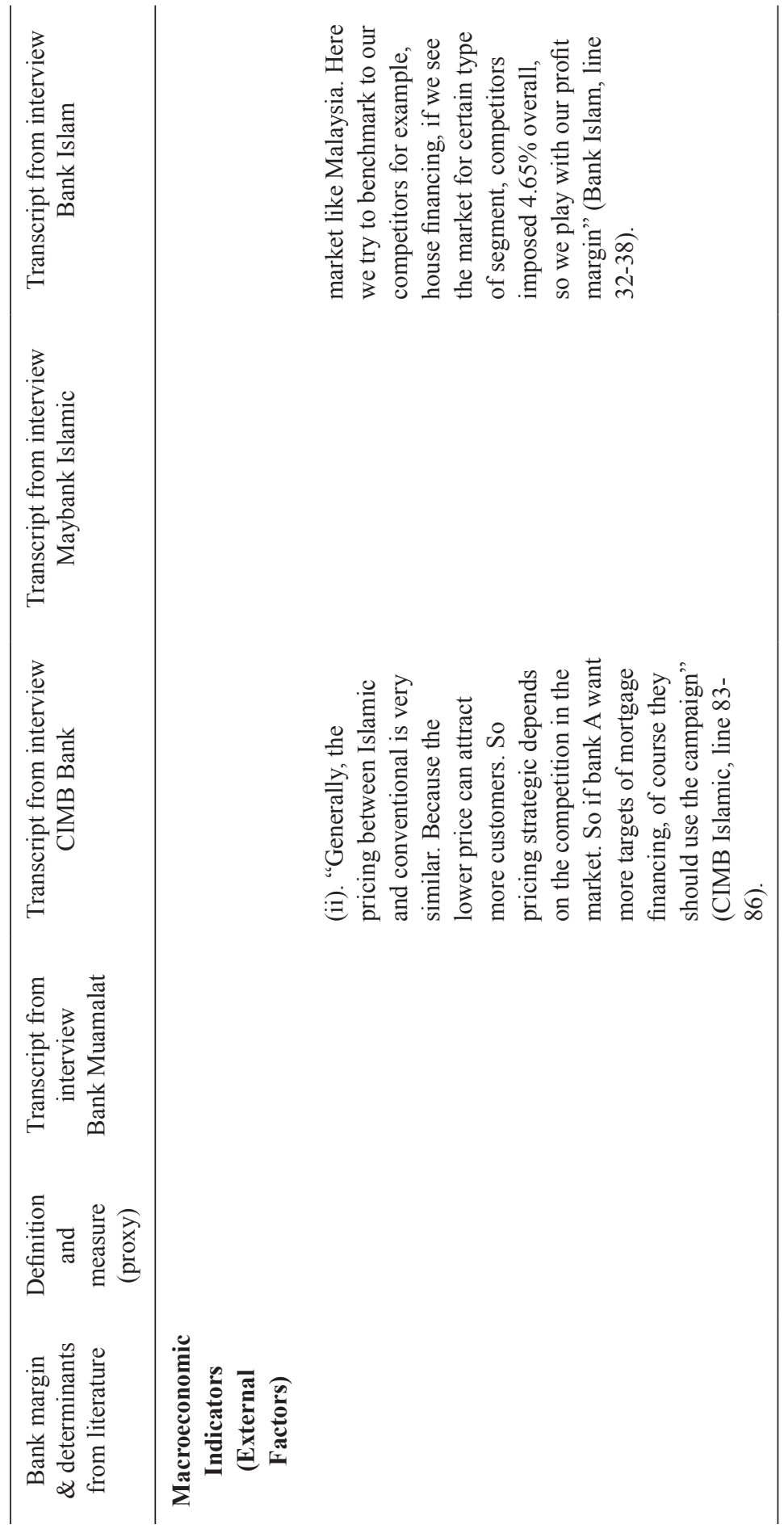

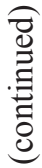




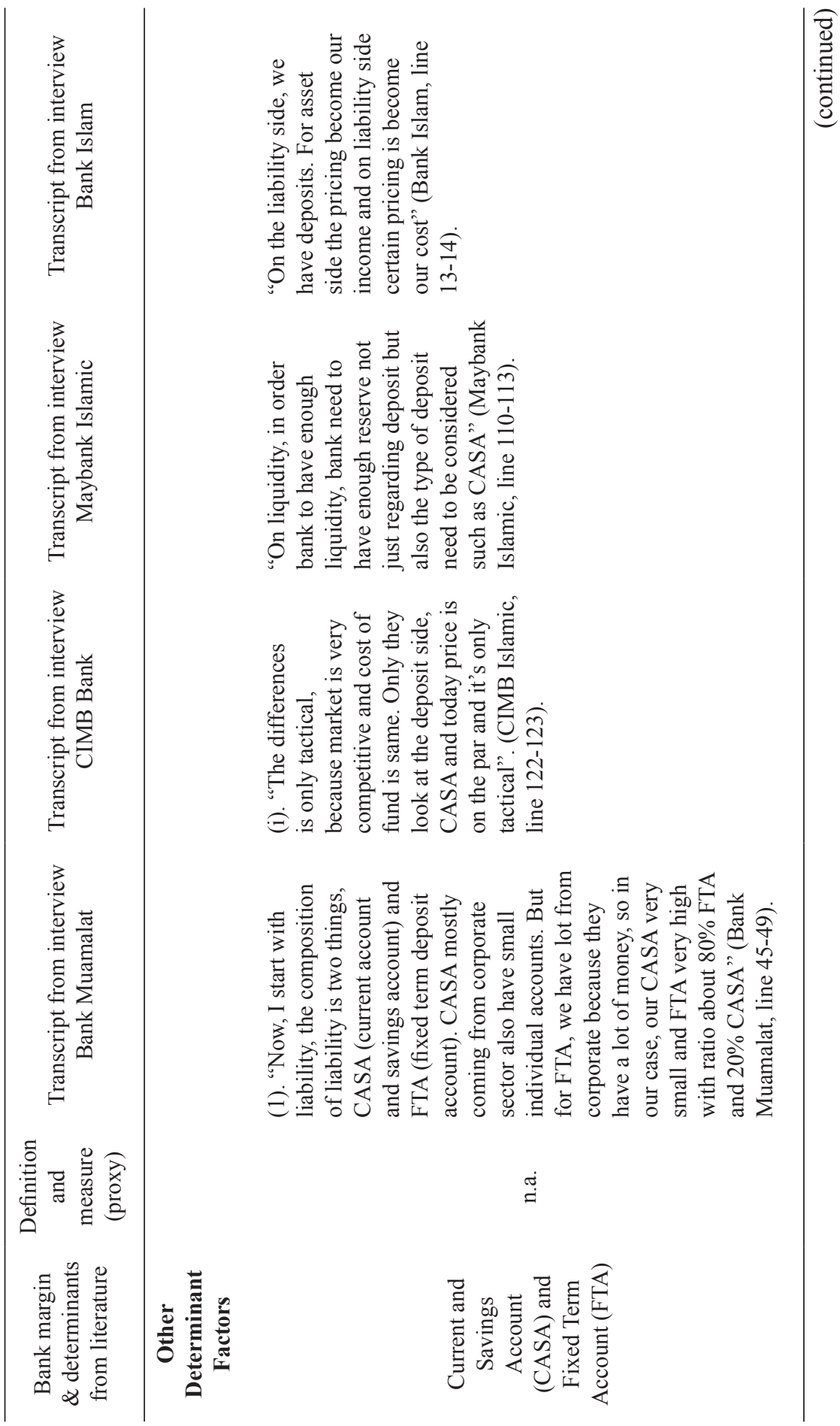




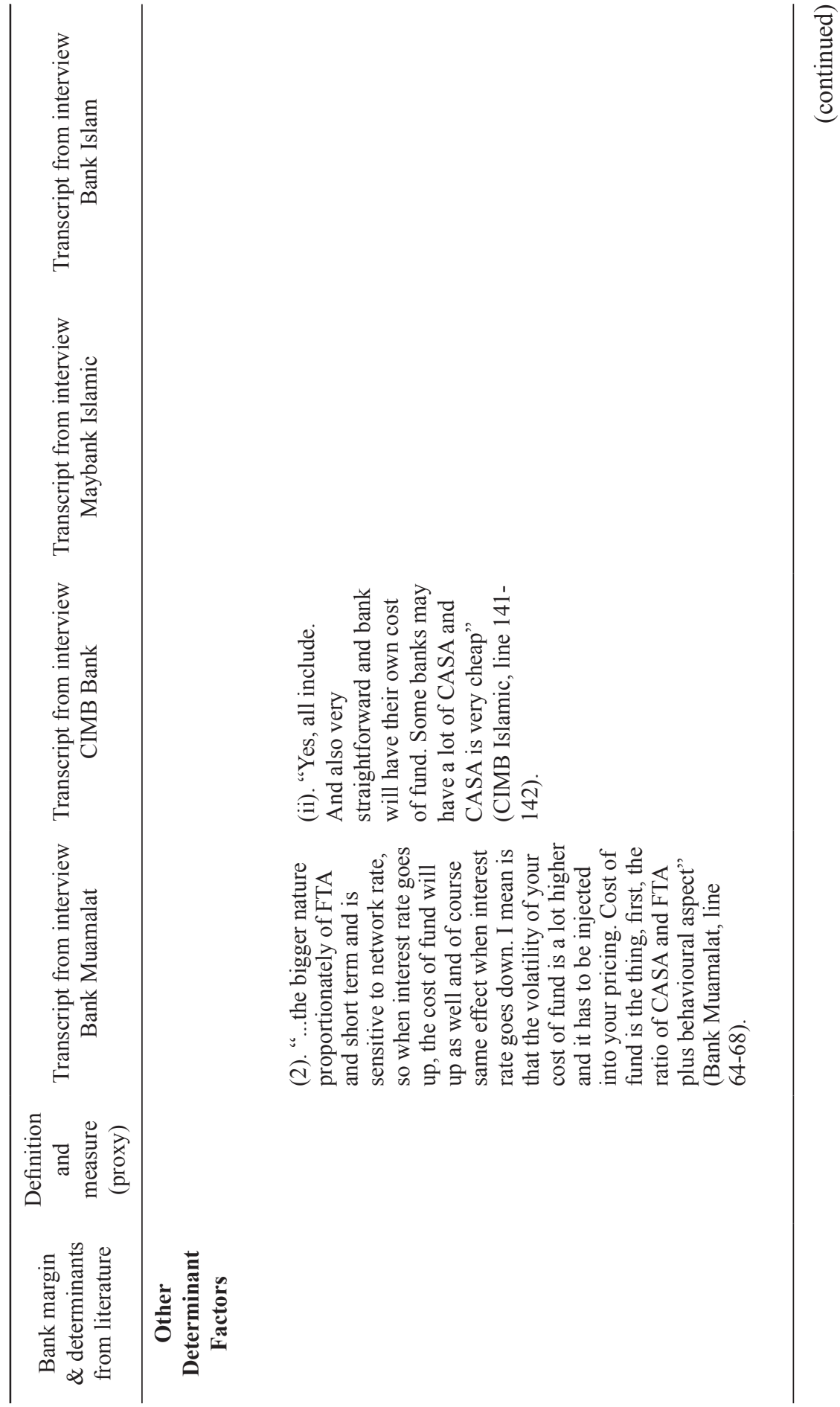




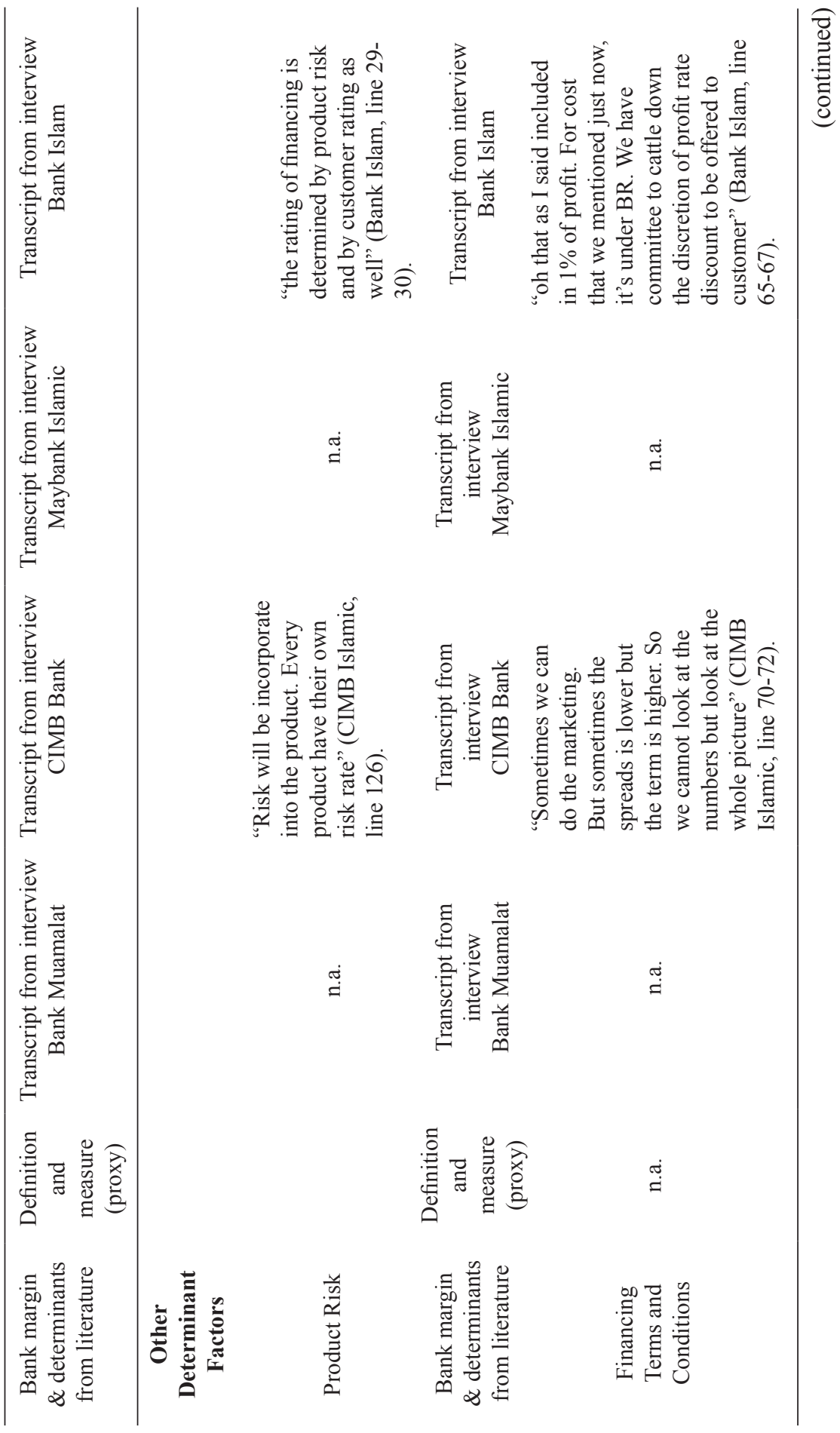




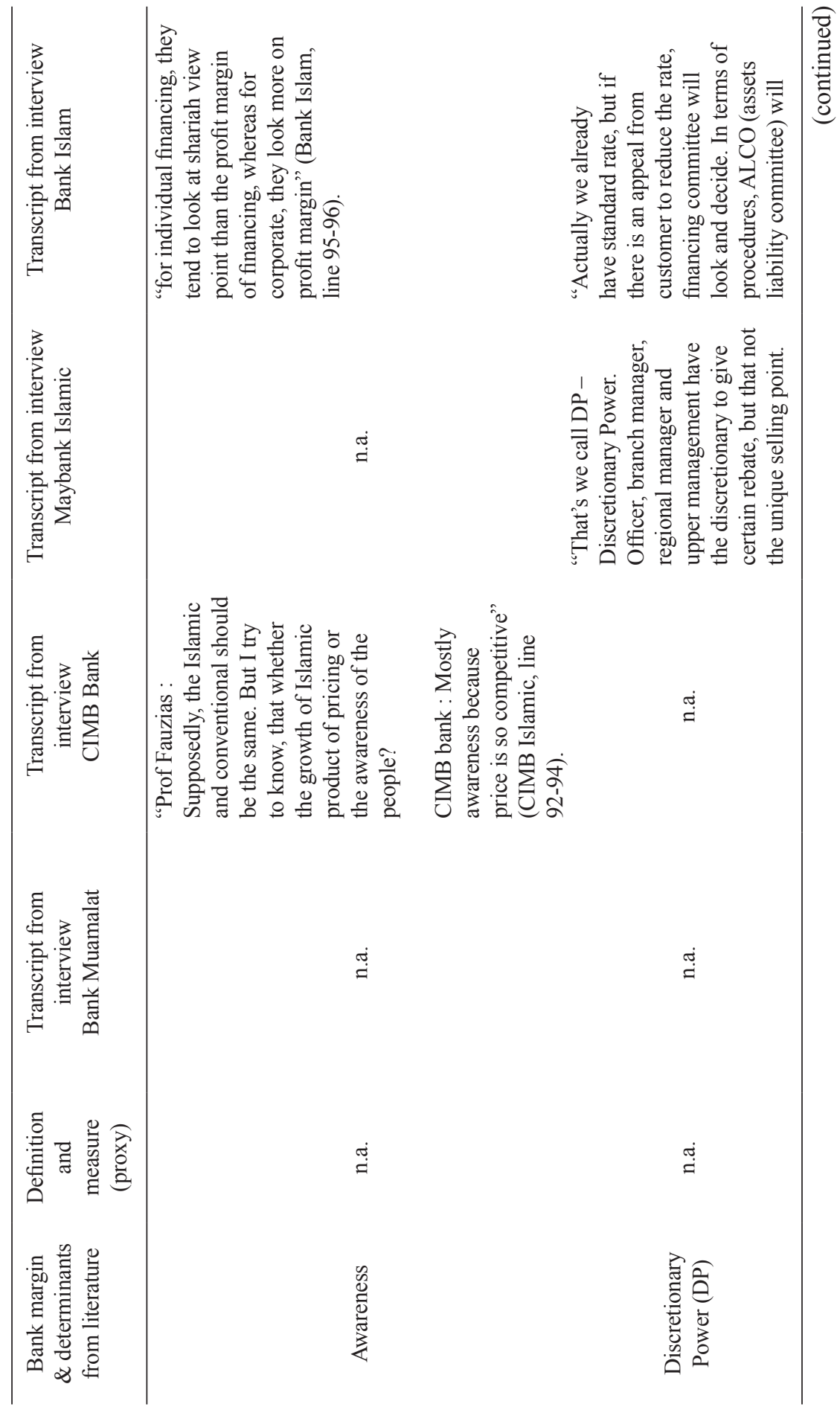




\begin{tabular}{|c|c|}
\hline 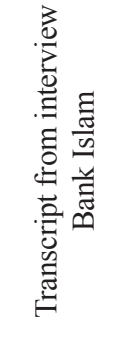 & 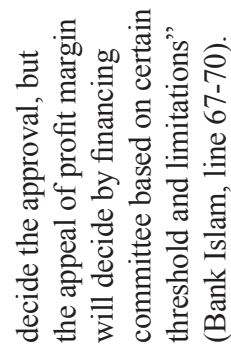 \\
\hline 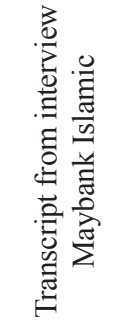 & 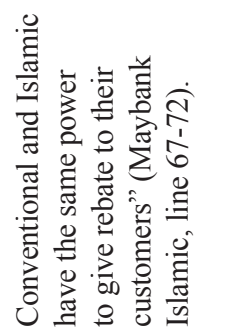 \\
\hline 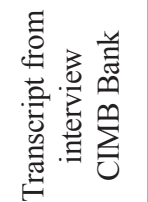 & $\stackrel{\text { }}{\stackrel{\leftrightarrow}{~}}$ \\
\hline 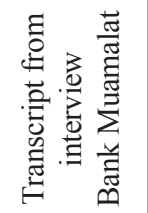 & $\stackrel{\text { }}{\text { ப் }}$ \\
\hline 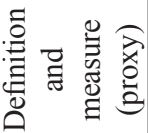 & 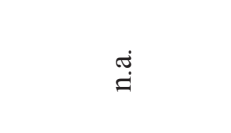 \\
\hline 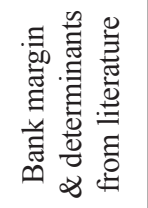 & 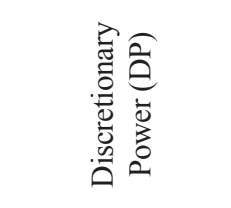 \\
\hline
\end{tabular}




\subsection{Analysis of Findings}

In general, bank profitability can be defined as the spread of interest income minus interest expenses to total assets (Oliver et al., 2015), whereby the net interest income set by Islamic banks is to cover the cost of intermediaries, reflecting both the volume and mix of assets and liabilities (Jane et al., 2012). Bank Islam cannot predetermine the portion of returns to pay the depositors as it violates shariah rules (riba). The deposit or financing rate of Islamic banks is known as ex-ante, while equity based product is known as ex-post, and taken together, overall, the Islamic banks by nature is ex-post (Erwin \& Rahmatina, 2010). Thus, the net interest margin of Islamic banks is known as ex-post. The following is a detailed discussion on the research questions.

The first question of the focus group interviews was regarding policies which guided pricing practices. Annual reports and interviews indicated that pricing policies were formulated and governed by bank management under a policy framework set up by the board of directors which was also reflected under a risk framework. Maximum risk tolerances and financing compositions between retail and corporate were adhered by bank management. Analysis conducted on annual reports showed that pricing policies were linked to management policy. For example, in terms of financing, results from interviews showed that Islamic banks have to create pricing policies based on a framework that has been gazetted whether retail composition is more or less as compared to corporate financing. This approach has taken due to several reasons, but one of it perhaps, is to reduce displacement risk, especially when huge corporations move their funds to other banks. As stressed in the following interview statements:

(i) "Now we talking about the treasury activity, i think it normally for conventional bank it's between 20\% to $30 \%$ and you find out that Islamic bank contribution probably at the lower end" (Bank Muamalat, line 17-18).

(ii) "Every bank has got percentage maybe 50\% auto and 40\% home finance, $30 \%$ credit card. They have risk capital target, no two banks is same. Every bank has their own risk appetite..." (CIMB Islamic, line 61-63).

(iii) "Our BOD predominantly focus on retail but we have present also in corporate financing. Corporate will increase our growth. Here we manage our risk through 70\% retail (less risk) and 30\% corporate (more risk), i.e. displacement risk. Thus, retail financing served as the cushion when displacement risk occurred" (Bank Islam, line 137-140).

(iv) "If you don't mind, i tell you a bit about our brand, Bank Islam and Muamalat bank are the stand alone bank and they have dedicated personnel management, 
risk management and IT department. For leverage model, even though they are subsidiary, they are are separate entitiy from their parent company. Now, when $i$ say leverage model, there are certain functions and infrastructures that we ride on them and we don't call conventional banking anymore, we call Maybank group" (Maybank Islamic, line 10-15).

The second question of the focus group interviews was regarding the department that handled pricing practices. This department is entrusted by management to formulate, manage and control pricing strategies based on a framework that is set up by the board of directors in order to maximise profit and minimise costs involved. Certain Islamic banks such as Bank Muamalat Berhad and Maybank Islamic Berhad have a special department to manage pricing policy. While, Bank Islam Malaysia Berhad has set up a special committee, i.e. assets liability committee (ALCO) to manage pricing policy. CIMB Islamic Bank Berhad has a different approach to manage pricing policy.

(i) "If you don't mind, i tell you a bit about our brand, Bank Islam and Muamalat bank are the stand alone bank and they have dedicated personnel management, risk management and IT department" (Maybank Islamic, line 10-12).

(ii) "Actually we already have standard rate, but if there is an appeal from customer to reduce the rate, financing committee will look and decide. In terms of procedures, ALCO (assets liability committee) will decide the approval, but the appeal of profit margin will decide by financing committee based on certain threshold and limitations" (Bank Islam, line 67-70).

(iii) "ok, different bank have different roadmap, have different role, some as enforcer like policemen. But there are also like muamalat, we try to facilitate the business" (Bank Muamalat, line 101-102).

(iv) "Special committee at HQ level has been entrusted to manage the pricing policy. Branches will process the financing application but Committte at $H Q$ will assess and approve the application" (CIMB Islamic, line 24-25).

The third question of the focus group interviews was regarding pricing practices. There were several aspects to be investigated under pricing practices, by way of the focus group interviews - whether a discretionary, rigid or flexible style of pricing practice has been adopted by Islamic banks. Results of the focus group interviews revealed that overall, Islamic banks have adopted a discretionary and flexible style of pricing practice due to the dynamics of economic volatility, stiff competition and high expectations from customers. The following statements were expressed by the respondents: 
(i) "ok, different bank have different road map, have different role, some as enforcer like policemen. But there are also like muamalat, we try to facilitate the business. The moral hazard is one have capacity to pay the other one willingness to pay" (Bank Muamalat, line 101-103).

(ii) "Bank can play with both of the BR and 1\%, meaning credit scoring will be reflect within BR and 1\%” (Bank Islam, line 72-73).

(iii) "Because of the risk exposure, we have cost of fund and credit spread. We apply the same whether for conventional or Islamic financing. Cost of fund follow KLIBOR benchmark. For the one year we follow MGS, while for more than twelve months, we follow KLIBOR" (Maybank Islamic, line 127-130).

(iv) "its about the market, if you lower base rate, then the spreads will be higher. For example CIMB Islamic Bank Berhad has base rate of 3\% and 1\% is spreads. Sometimes we can do the marketing. But sometimes the spreads is lower but the term is higher. So we cannot look at the numbers but look at the whole picture" (CIMB Islamic, line 71-74).

The fourth question of the focus group interviews, was regarding the overall objective of price setting. This aspect has been pre-ascertained based on literature, whether Islamic banks apply stable growth or positive objective regarding price setting. This aspect has been considered as paramount to Islamic banks as it would determine the bank's lifelong economic stream. As per conversation with the top management of Islamic banks, the exponential growth of the banks' business is crucial and essential for bank continuity in the long run. Thus, strategic and holistic efforts towards bank growth is the prime task for all bank subordinates. Besides other income such as fee based, the main business of Islamic banks are depositing and financing - these aspects are formulated, monitored and evaluated to ensure that growth objective is achieved. The following statements stress on growth target as indicated in the focus group interviews:

(i) "of course you want a growth from year-to-year. I think the combination of more volume and more business but as well as more efficient" (Bank Muamalat, line 107-108).

(ii) "We want exponential growth. We want to grow as big as we want" (Maybank Islamic, line 199).

(iii) "Yes, it can be changed, but the retail you cannot increase in one night because of volume and small in size of financing. Whereas corporate can increase the business within shorter period of time because of the large size of financing. 
Our BOD predominantly focus on retail but we have present also in the corporate financing. Corporate will increase our growth. Here we manage our risk through 70\% retail (less risk) and 30\% corporate (more risk), i.e. displacement risk. Thus, retail financing served as the cushion when displacement risk occurred" (Bank Islam, line 154-161).

(iv) "Of course we have certain target of growth" (CIMB Islamic, line 201).

Lastly, the fifth question of the focus group interviews concerned the determinants of bank margins. A number of themes which emerged from the interviews conformed to the literature. However, there were other themes that differed from the literature and it seemed that there were differences between academic theory(s) and the approaches practised by the banking industry.

The following sections are detailed discussions regarding the theme of bank margin determinants that emerged from the interviews which concurred with referred literature. This is followed by a discussion of new findings from the focus group interviews:

(1) The first theme that was elicited was management efficiency, which was regarded as efficiency in managing business operations. Management efficiency is regarded as the ability of management to minimise costs at a given level of income or to maximise income at a reasonable level of cost (Erwin \& Rahmatina, 2010). According to literature, management efficiency is negatively related to bank margins, i.e. as the efficiency of Islamic banks improves, the banks would be able to reduce costs and thus will be able to offer relatively lower margins to their customers. Results from the interviews have implicitly stressed that Islamic banks have to be efficient in their banking business in order to achieve profit targets. The following are statements from the interviews:

(i). "Of course we have certain target of profit" (CIMB Islamic, line 97).

(ii). "we look at all factors such as the size and the assets and the percentage of return also must be on par, you cannot compromise on that" (CIMB Islamic, line 99-100).

(iii) "In terms of Islamic principles, we need to be shariah compliance but we need also to be competitive as well and in order to be competitive, our pricing need to follow market trend even though the pricing was computed according to pricing components, but at the end we need to follow market rate in order not to lose market share to competitors" (Bank Islam, line 82-86).

(2) The second theme elicited from the focus group interview was the operating expenses of Islamic banks from costs incurred through financial intermediaries 
such as screening financing applications to assess the risk profile of borrowers, and customer acquisition cost, i.e. promotions and advertisements. An increase in operating cost is expected to have a positive influence on financing rate spread. Higher operating cost will lead to higher financing rate and lowers the deposit rate as expressed by the following respondents:

(i). "it's not easy to get customers, acquisition cost is very high, advertisement cost, promotion and campaign and all those things..." (Bank Muamalat, line 54-55).

(ii). "Operating expenses is same. It regarding certain expenses incurred by bank such as IT expenses, infrastructure or to set up branch" (Maybank Islamic, line 166-167).

(iii) "Our MD said, Bank Islam is the smallest among the big banks, but biggest among small banks. Bank Islam is actually compete in retail section, assets compositions of bank Islam is 75\% retail and 25\% is corporate” (Bank Islam, line 76-78).

(3) The third theme which emerged from the interview exercise was bank size, which can be expected as the larger the bank the higher its capability to reach customers. Normally larger banks are associated with lower financing rate spread because of economies of scale and the ability to invest in the latest technology which would enhance efficiency. Thus, with a better control of the market, it is not surprising that there is a positive relationship between bank spread and bank size. The following are stated by respondents regarding bank size being significant in improving bank profitability:

(i). "Price network which basically economies of scale. If we have bigger reach, so it not much critical to have a network...” (Bank Muamalat, line 53-54).

(ii). "For your information, our composition of business within Maybank banking group is about $52 \%$ of total loan and we are the biggest contribution. In Islamic banking space, we are already big and sizeable. We are number two in terms of size, number one is bank rakyat if we consider them as Islamic institution" (Maybank Islamic, line 15-19).

(4) The fourth theme elicited from the interviews was liquidity risk. This is the risk concerning Islamic banks not having sufficient cash or borrowing capacity to meet deposit withdrawals or financing demands, which will lead the banks to borrow from emergency funds at higher cost. According to Santiago and Francisco (2007), if the liquidity risk of the banks increases, the banks will ask 
for a higher risk liquidity premium. The banks will increase its finance rate so that the Islamic banks' net interest income will increase as well. Hence, the Islamic banks' net interest income will respond positively to liquidity risk. There are a number of proxies to measure liquidity ratio, i.e. total loan to total asset and total financing to total deposits (Sufian \& Abdullah, 2010; Kosmidou et al., 2005). The ratio shows the relationship between liquidity and bank margins. Financing is the largest component of interest bearing assets of a bank and is expected to have a positive impact on profitability (Sufian \& Abdullah, 2010). Profit is expected to be higher when more deposits are transferred into financing, thus, it is assumed that there is a positive relationship with profitability. As emphasised by respondents in the following statements that Islamic banks are always prudent in handling deposits as well as the financing side due to unmatched timing between deposit and financing:

(i). "Because fractional banking system, we take in deposit then we lend it to customer. Islamic bank manage liability independently from asset. In terms of distributing, you always look at whatever you can have from your asset then only you pay your depositors right?

The moral hazard is this, if you take some risky financing and you lose money, you tend not to pass on the loss to the customer because we may not get the funding. Then you tend to absorb at the bank level. But when you make a lot af money you don't have any option, you have to put in your reserve which may not count for profit and goes to shareholders or you have to distribute as a dividend" (Bank Muamalat, line 2-10).

(ii). "We are governed under Basel III, Basel III is more on liquidity, Basel II is on capital. On liquidity, in order bank to have enough liquidity, bank need to have enough reserve not just regarding deposit but also the type of deposit need to be considered..." (Maybank Islamic, line 110-113).

(iii) "This is the big issue that bank Islam need to be carefully managed. Yes, because of compliance, we monitor maturity mismatch and this matter has been managed by risk department and treasury. Often we borrow short and then finance long, that the problem facing by retail banking" (Bank Islam, line 113116).

(5) The fifth theme was credit risk. If a bank foresees a high risk operation, then the bank will charge a higher risk premium which will subsequently increase the bank's margin. The bank will incorporate credit risk into pricing through a credit scoring assessment. The following was expressed by the respondents:

(i). "The BR doesn't change, everybody follow that right? But the spread change according to rating of the customer. When customer comes to the bank asking for 
whatever financing, you subject them to the scoring system, the scoring system probably for example, the rating 1 to 10 right? You would aspect rating 1 have smallest spread, the rating 10 would be highest spread" (Bank Muamalat, line 85-89).

(ii). "Logically, the system will be pick up one IC, except the person has two identity cards. Except you are in the different working place, perhaps after 6 monthly and then you apply. Maybe credit scoring will be different" (CIMB Islamic, line 55-5).

(iii). "In our Islamic finance, we have different type of contracts whether using equity based or debt based. In terms of risk its same for conventional or Islamic financing, the credit risk exposure when customer not make payment or customer defaulting. In Islamic financing we have several contracts, for equity based, i.e. musyarakah mutanaqisah, mudharabah and ijarah, while, for debt based are ijarah, murabahah and etc." (Maybank Islamic, line 75-79).

(iv) "Yes, in terms of risk it same between Islamic bank and conventional bank. All banks have to follow the Basel requirement as enforced by respective financial regulators. It is the matter of the asset of the bank that makes it different. For example Bank Islam, we have many market instruments same as conventional bank" (Bank Islam, line 136-139).

(6) The sixth theme which emerged from the interviews was default risk. The interviewees had stressed that the risk involved in determining the bank's margin should be carefully planned in order to minimise risks. Default risk is the risk of non-repayment on financing due to fund users' inability to fulfil their obligations. Since financing is the main source of income for banks, deterioration of financing quality will affect the bank's ability to lend to other customers and will definitely affect profitability and subsequently the bank's viability. As the default risk is higher, the bank will put a higher risk premium on financing, then the price of financing will increase so will the bank's profitability. The following are statements from the interviews:

(i) "Yes, we can. Because the nature of the contract like musyarakah, mutanaqisah or wakallah or ijarah. We can own the asset as opposed to the conventional banking, they cannot own the asset directly unless they set up the special vehicle to run the project. Islamic bank in Malaysia can do everything including investment banking, PE-private equity, the licence allows to do that, but we can't because of the risk" (Maybank Islamic, line 86-91).

(ii) "Diminishing, it's ok. We have done that even we have 4.4 billion of MM. But MM has not yet been tested in court. Because of an ijarah element in the 
contract. It's normally concerned for for property under construction. The risk is more on developer. Should developer fails to accomplish the project, than it will affect the customer financing with the bank. In abandoned project, customer has paid the instalment, then based on MM contract, bank has to pay back customer due to the negligence by developer" (Maybank Islamic, line 150-155).

(iii) "the rating of financing is determined by product risk and by customer rating as well. So they have different rating as well in computing the base rate (BR)" (Bank Islam, line 29-30).

(7) The seventh theme concerned capital adequacy ratio. This is the condition imposed by Bank Negara Malaysia and also there are certain guidelines from Basel III (which require banks to fund themselves with $4.5 \%$ of common equity). The capital ratio is the amount of capital a bank or other financial institution has to hold as required by its financial regulator. This is usually expressed as a capital adequacy ratio of equity that must be held as a percentage of risk-weighted assets. These requirements are put in place to ensure that these institutions do not take on excess leverage and become insolvent. Capital requirements govern the ratio of equity to debt, recorded on the liabilities and equity side of a firm's balance sheet. They should not be confused with reserve requirements, which govern the assets side of a bank's balance sheet, in particular, the proportion of assets it must hold in cash or highly liquid assets. The following statements are from the respondents regarding capital adequacy:

(i) "We are governed under Basel III, Basel III is more on liquidity, Basel II is on capital. On liquidity, in order bank to have enough liquidity, bank need to have enough reserve not just regarding deposit but also the type of deposit need to be considered...." (Maybank Islamic, line 110-113).

(ii) "Central Bank had in stages enforced the requirements. Currently the requirement that enforced is LCR (Liquidity Coverage Ratio) and for the Net Stable Financing Ratio, it will be implemented gradually. For example, for LCR Central Bank has required that requirement has to be fully enforced on 2018, starting with 60\% within six months on 2015" (Bank Islam, line 131-134).

(8) The eighth theme obtained from the interviews was non-interest bearing asset (fee based). This measure effectively captures all sources of non interest income generated by diversified Islamic banks. This determinant is also considered as a shift from traditional financial intermediation to other banking activities in order to compensate for declining profitability or as extra income for Islamic banks. According to Oliver et al. (2015), banks are willing to incorporate non interest income activities in order to boost bank profit. The result has shown that the 
increase in non interest income will lower corresponding financing rate charges and subsequently will lower net interest income. According to the respondent from Bank Muamalat, non interest activities derived such as, from operating account with Islamic bank is considered as collateral to the financing offered to customers. The bank can charge certain fees under operating account, such as processing fee, account maintenance fee, etc., as noted in the following theme:

(i). "Now, if you have operating account and also a financing, so what do you think they gonna price the pricing? They look at total relationship, everything is goes through the bank, so they can optimise the pricing right?" (Bank Muamalat, line 67-69).

(ii). “ Same. Fee based. No different between conventional or Islamic banks. My experience is same. As for Maybank because we ride on parent company's retained. That's why leverage model has lower price due to lower cost of fund obtained from parent company" (Maybank Islamic, line 168-172).

(iii) "Yes, and we also have section that manage the Sukuk offering" (Bank Islam, line 109).

(9) The ninth theme that was elicited from the focus group interviews was market interest rate volatility. Based on literature, generally banks would ask for higher margins when interest rate increases. In comparison to past years, presently Islamic banks in Malaysia are using the floating rate approach in their financing. Thus exposure to market rate volatility faced by Islamic banks is similar to conventional banks. That is, when market rate increases, Islamic banks need to increase their financing rate in order to compensate for the higher market rate. Hence when the market rate swings - whether it increases or decreases, Islamic banks would adjust their rate of financing accordingly. For example, under Bank Islam Malaysia Berhad, the component that can be re-evaluted if cost increased is the bank financing rate (BFR). This adjustment can be done with the approval from Central Bank. The other part of profit margin is bank spread. This part cannot be adjusted once it has been sealed with the customer. This issue can be further clarified from the following statements:

(i) "As for base rate components, we cannot simply change without approval from Bank Negara. We need to show that the cost has moved in order to increase the base rate. The way we contracted with customer, we say that based on base rate plus certain profit and if base rate moves then instalment amount will moves as well. The one that we fix with customer is spread (profit margin) but base rate not fix with customer. Of coz we can change BR anytime but subject to Bank Negara Approval” (Bank Islam, line 41-46). 
(ii). "Now, 80\% of FTA (Fix Term Account) is very sensitive, so market interest rate will reflect of whole market funding” (Bank Muamalat, line 48).

(iii). "Let's see in Islamic bank for example they fixed at $5 \%$ rate and then the Islamic bank will put on 1\% as buffer. Why? The reasons is when the price increase, you cannot say I want to renegotiate the contract, from $6 \%$ to $8 \%$ " (CIMB Islamic, line 41-42).

(iv). "My contention is not whether on leverage or stand alone models. It depends on the rating of the bank. Because, if I want to place money with you, I look at the rating. It's like giving credit. For Islamic banks, we are quite young, our rating are not that good from balance sheet point of view and capital also not that big enough and because of that the cost of fund will be expensive. When people want to place money, especially foreign institutions, they look at your rating” (Maybank Islamic, line 159-164).

(10) The tenth theme that emerged from the interview was market concentration. There are contrasting views on the relationship between market concentration and net interest margin. Some researchers noted that a concentrated market will enhance bank power to increase interest margins (Porter, 1979). Anthony and Liliana (2000) also found that market concentration had a positive relationship with spread, whereby the larger appears to be monopoly power of existing banks, the higher the bank margin. Empirical results from a research in Malaysia conducted by Abduh and Yameen (2013) showed that the market is highly concentrated with profitability. However, from the interviews conducted, it is not clear as to the effect of market concentration on net interest income. Despite this, respondents from Bank Muamalat implied that banks with smaller capital will have less power to influence the market, whereas banks with higher market share and more market reach are capable of offering lower financing rates in order to attract customers. Thus, a lower financing rate will attract more customers and therefore a higher profit for banks as indicated in the following statements:

(i) "The smaller the bank the higher the acquisition cost, this cost of investment will go to your cost, I mean in terms of ratio of asset size, they will be very high proportionately and there's nothing new.

(Stressed by Prof, no wonder they want to merge) and it was agreed by respondent" (Bank Muamalat, line 57-60).

(ii) "Currently in Islamic banking, Bank Islam is ranked third, number one is AlRajhi Bank or Kuwait Finance House, but number one in Malaysia is Maybank Islamic Bank Berhad, second CIMB Islamic Bank Berhad and third is Bank Islam Malaysia Berhad” (Bank Islam, line 178-181). 
(11) The eleventh theme that emerged from the focus group exercise was competition. This element of pricing was repeatedly stressed by respondents. It is obvious that competition has direct impact on pricing structure whereby Islamic banks take into consideration the element of marketing campaign to promote their financing products. Banks will hold special campaigns on financing facilities in order to attract customers. On certain occasions, banks will normally offer a lower financing rate to spur certain financing products such as the balloon scheme for auto financing by Bank Islam Malaysia Berhad. This campaign offers a staggered financing rate starting with a lower financing rate for certain years and increasing the financing rate for subsequent years until the end of the financing period. As stated by respondents, market competition is high due to the many players involved in the Islamic banking industry in Malaysia. Each bank will try to attract customers with their own promotion of financing. However, the larger banks will have competitive advantage due to economies of scale, a larger network and larger customer reach. Below are statements from interviews with respondents:

(i). "Pricing is actually based on supply and demand equilibrium, yes you can look at the cost factor going into that pricing of the product, but you need to look at market competition of Islamic banks...." (Bank Muamalat, line 31-33).

(ii). "Generally, the pricing between Islamic and conventional is very similar. Because the lower price can attract more customers. So pricing strategic depends on the competition in the market. So if bank $A$ want more targets of mortgage financing, of course they should use the campaign" (CIMB Islamic, line 83-86).

(iii). "Competition is very tensed actually, because all banks have done Islamic financing and they also realised that conventional market is very crowded" (Maybank Islamic, line 190-192).

(iv) "All banks have their own base rate, for Bank Islam our base rate is currently at 3.6\% (liquidity cost and credit risk cost), and on top of base rate components, we have profit margin that would become our spread, that means $B R+0.6$ and that amount of spread is really competitive in such market like Malaysia. Here we try to benchmark to our competitors for example, house financing, if we see the market for certain type of segment, competitors imposed $4.65 \%$ overall, so we play with our profit margin" (Bank Islam, line 32-38).

\subsection{New Findings of Profit Margin}

There were certain themes however, that were not specifically stated in the literature which emerged from the focus group interviews as they appeared in the 
determination of pricing structure exercised by Islamic banks. It is paramount for Islamic banks to consider any element that affects profit margin in order to stay alive in the business. The following are the themes which emerged from the interviews:

(1) First, one of the themes that emerged from the interviews was the liabilities item under a bank's balance sheet. As stressed by the respondents, the element of Current Account and Savings Account (CASA) plays an important role in pricing formulation. The percentages of CASA will influence the financing rate offered to customers as it is factored in the calculation of the cost of funds. According to Bank Muamalat, the element of CASA and FTA (Fixed Term Account) will affect the pricing structure of banks, however, bank size is also taken into account. For smaller banks like Bank Muamalat, the amount of CASA is small as compared to FTA, but for larger banks like Maybank Islamic Berhad, the CASA component has a significant effect in the pricing structure. Furthermore, as noted by the respondent from CIMB Islamic Bank, the amount of CASA contributed more in terms of bank capital. CASA is cheaper in terms of cost of funds compared to other source of funds like FTA or funds from the interbank money market. The following are statements elicited from the interviews:

(i). "Now, i start with liability, the composition of liability is two things, CASA (current account and savings account) and FTA (fixed terms deposit account. CASA mostly coming from corporate sector also have small individual accounts. But for FTA, we have lot from corporate because they have a lot of money, so in our case, our CASA very small and FTA very high with ratio about $80 \%$ FTA and 20\% CASA" (Bank Muamalat, line 45-49).

(ii). ".....the bigger nature proportionately of FTA and short term and it sensitive to network rate, so when interest rate goes up, the cost of fund will up as well and of course same effect when interest rate goes down. I mean is that the volatility of your cost of fund is a lot higher and it has to be injected into your pricing. Cost of fund is the thing, first, the ratio of CASA and FTA plus behavioural aspect" (Bank Muamalat, line 64-68).

(iii). "The differences is only tactical, because market is very competitive and cost of fund is same. Only they look at the deposit side, CASA and today price is on the par and it's only tactical" (CIMB Islamic, line 122-123).

(iv). "Yes, all include. And also very straightforward and bank will have their own cost of fund. Some bank may have a lot of CASA and CASA is very cheap" (CIMB Islamic, line 122-123). 
(v). "On liquidity, in order bank to have enough liquidity, bank need to have enough reserve not just regarding deposit but also the type of deposit need to be considered such as CASA" (Maybank Islamic, line 110-113).

(vi) "On the liability side, we have deposits. For asset side the pricing become our income and on liability side certain pricing is become our cost" (Bank Islam, line 13-14).

(2) The second theme that emerged from the interview was product risk. Product risk premium is pre-formulated by banks. According to the respondent from CIMB Islamic, each product has its own risk, therefore a bank will assign a risk rate premium to a particular product. Thus, when the bank has determined the financing rate to its customers, the bank will incorporate the product risk premium according to the financing product acquired by the customers. The following are statements from respondents which expressed the said theme:

(i) "Risk will be incorporate into the product. Every product have their own risk rate” (CIMB Islamic, line 126).

(ii) "the rating of financing is determined by product risk and by customer rating as well” (Bank Islam, line 29-30).

(3) The third theme which emerged from the interview was financing terms, whereby the terms affect the pricing of product financing. In order to attract customers, Islamic banks will offer special promotions regarding margin rates. This offer comes with certain conditions. For example, the bank will offer a lower financing rate when the customer applies for a longer period of financing or the customer applies for financing which exceeds a certain financing amount. As expressed by CIMB Islamic Bank's respondent in the interview:

(i) "Sometimes we can do the marketing. But sometimes the spreads is lower but the term is higher. So we cannot look at the numbers but look at the whole picture" (CIMB Islamic, line 70-72).

(ii) "oh that as I said included in 1\% of profit. For cost that we mentioned just now, it's under BR. We have committee to cattle down the discretion of profit rate discount to be offered to customer" (Bank Islam, line 65-67).

(4) The fourth theme that was evident from the interview was regarding awareness of the customer. Texts from the interviews showed that awareness of Islamic values was the main reason customers selected Islamic banks. Due to the awareness of Islamic principles, Moslem customers will certainly choose Islamic 
banks, even though conventional banks offered similar financing products. Thus, the awareness factor will contribute to the growth of Islamic banks. The following are statements from the interviews:

(i) "Prof Fauzias: Supposedly, the Islamic and conventional should be the same. But I try to know, that whether the growth of Islamic product of pricing or the awareness of the people?

CIMB Islamic Bank: Mostly awareness because price is so competitive” (CIMB Islamic, line 92-94).

(ii) "for individual financing, they tend to look at shariah view point than the profit margin of financing, whereas for corporate, they look more on profit margin” (Bank Islam, line 95-96).

(5) The fifth theme that was uncovered was regarding negotiation power handed down by Islamic banks to their officers. The credit officer can bargain with prospective customers regarding product price. This is one of the selling points that bank officers can promote and also close deals with customers. Maybank Islamic Berhad has given exclusive rights to their officers to offer a certain point of reduction in profit margin as a bargaining tool. This is called Discretionary Power (DP). The following statements from the interviews underlines the point mentioned:

(i) “That's we call DP - Discretionary Power. Officer, branch manager, regional manager and upper management have the discretionary to give certain rebate, but that not the unique selling point. Conventional and Islamic have the same power to give rebate to their customers" (Maybank Islamic, line 67-72).

(ii) "Actually we already have standard rate, but if there is an appeal from customer to reduce the rate, financing committee will look and decide. In terms of procedures, ALCO (assets liability committee) will decide the approval, but the appeal of profit margin will decide by financing committee based on certain threshold and limitations" (Bank Islam, line 67-70).

Based on above analysis, there were certain determinants which emerged from texts that were elicited from the focus group interviews with respondents from Bank Muamalat and CIMB Islamic Bank. The themes which concurred with literature included default and credit risk, operating expenses, bank size, market interest rate volatility and competition, while determinants that were not mentioned in the literature included liability items (Current Account and Savings Account - CASA and Fixed Terms Account - FTA), product risk and financing terms and discretionary power (DP). Clearly, there is a slightly different 
approach practised by Islamic banks in setting up prices for financing products as compared to theoretical practices. The focus group interviews have revealed the actual practices by Islamic banks regarding the pricing of financing products in Malaysia.

\section{Conclusion and Recommendations for Future Studies}

A qualitative approach was used in conducting the study. This approach was employed in order to gain an understanding of the real situation regarding pricing practices by Islamic banks in Malaysia. The focus group exercise was used as a method to collect data. In particular, the focus group was developed to gather insights and opinions from experts in Islamic banking.

The intention of the focus group interviews was to clarify guided policies, responsibilities of departments, pricing practices, overall objectives and to validate and explore new items of determinants not found in the literature. The focus group was intended to identify and clarify the exact determinant(s) of bank margins, pricing practices and also to explore new possible determinants for bank margins. Results from interviews showed that generally there are certain policies that were holistically formulated at the board level to guide pricing practices, such risk appetite. In addition, on the whole all Islamic banks have a special department assigned to handle pricing practices. With regards to pricing practices and bank objectives, results of the interviews also revealed that Islamic banks have a flexible approach in pricing practices due to economic challenges. As for overall objectives, generally all Islamic banks have targeted growth as the prime goal. In terms of determinants of profit margins, related literature has indicated several variables, such as liquidity risk, credit risk, default risk, capital adequacy ratio, non-interest margins, implicit returns to depositors, operating expenses, management efficiency, bank size, market interest rate volatility, market concentration, gross domestic product and competition.

Generally, the themes which emerged from the interviews were parallel with findings from literature. The profit margin determinants that were elicited from the interviews included default risk, credit risk, operating expenses, bank size, market interest rate volatility and competition. However, the determinants that have yet to be captured in the literature are marketing strategies which include product risk, financing terms and conditions and discretionary power (DP). Product risk is a risk that is predetermined according to product preferences, while financing terms concerns the offering of special financing rates with accompanying conditions to attract customers. Other important determinants of bank margins and profitability included awareness of Islamic banking products and cost of fund strategies. Therefore, further studies should be conducted in order to explore and validate other possible determinants of bank margins in different banking contexts. 


\section{References}

Abduh., \& Yameen, I. (2013). Determinants of Islamic Banking Profitability in Malaysia. Autralian Journal of Basic and Applied Sciences, 7(2), 204210.

Alhassan, A. L., \& Ohene-Asare, K. (2016). Competition and bank efficiency in emerging markets: Empirical evidence from Ghana. African Journal of Economic and Management Studies, 7(2), 268-288.

Anthony, S., \& Liliana, S. (2000). The Determinants of Bank Interest Rate Margins: An International Study. Journal of International Money and Finance. 19, 813-832.

Babbie, E. R. (2013). The Practice of Social Research (13 ${ }^{\text {th }}$ ed.). Wadsworth: Cengage Learning.

Bashir, A. M. (2003). Determinants of Profitability in Islamic Banks: Some Evidence from the Middle East. Islamic Economic Studies. 11(1), 31-57.

Berne, J. (2004). Think Aloud Protocol and Adult Learners. Adult Basic Education, 4(3), 153-173.

Chong, B. S., \& Liu, M. H. (2009). Islamic banking: Interest-free or interestbased? Pacific-Basin Finance Journal, 17, 125-144.

Daniel, K. T., Yonas, B. C., \& Milcah, M. (2012). Determinants of Net Interest Income of Commercial Banks in Kenya: A Panel Study. Procedia Economics and Finance, 2, 199-208.

Demirguc, K. A., \& Huizinga, H. (2001). Financial Structure and Bank Profitability in Financial Structure and Economic Growth: A CrossCountry Comparison of Banks, Markets and Development. United State: The MIT Press.

Erwin, G. H., \& Rahmatina, A. K. (2010). Bank Margin Determination: A Comparison between Islamic and Conventional Banks in Indonesia. International Journal of Islamic and Middle Eastern Finance and Management, 3(1), 65-82.

Fernanda, D. A., \& J. Angelo, D. (2015). Determinants of the Banking Spread in the Brazillian Economy: The Role of Micro and Macroeconomic Factors. International Review of Economics and Finance, 40, 29-39.

Hameed, M. B. (2003). Determinants of Profitability in Islamic Banks: Some Evidence from The Middle East. Islamic Economic Studies, 11(1), 3157.

Haron, S., \& Shanmugam, B. (1997). Islamic Banking System Concepts \& Applications. Selangor, Malaysia: Pelanduk Publications (M) Sdn Bhd.

Haron, S. (1996). Competition and Other External Determinants of the Profitability of Islam Banks. Islamic Economic Studies, 4(1), 49-66.

Haron, S. (2004). Determinants of Islamic Bank Profitability. Global Journal of Finance and Economics. 1(1), 1-22. 
Hassan, Z. (2007). Fifty Years of Malaysian Economic Development: Policies and Achievements. Review of Islamic Economics, 11(2), 101-118.

Ho, T., \& Saunders, A. (1981). The Determinants of Bank Interest Margins Theory and Empirical Evidence. Journal of Finance Quantitative Analysis, 16(4), 581-600.

Ilias, S. (2009). Islamic Finance: Overview and Policy Concerns. Congressional Research Service, 1-7.

Izahar, H., \& M. Asutay. (2007). Estimating the Profitability of Islamic Banking: Evidence from Bank Muamalat Indonesia. Review of Islamic Economics, 11(2), 17-29.

Jane, R. L., Huimin, C., Ming, H. H., \& Soushan, W. (2012). The Determinants of Interest Margins and their Effect on Bank Diversification: Evidence from Asian Banks. Journal of Financial Stability, 8, 96-106.

Joaquin, M., \& J. Fernandez, D. G. (2004). Factors Explaining the Interest Margin in the Banking Sectors of the European Union. Journal of Banking and Finance, 28, 2259-2281.

John, W. C. (2007). Qualitative Inquiry \& Research Design: Choosing Among Five Approaches ( $2^{\text {nd }}$ ed.). SAGE Publication.

Kamal Khir, Lokesh, G., \& Bala, S. (2009). Islamic Banking: A Practical Perspective. Kuala Lumpur: Pearson Longman.

Karwowski, E. (2009). Financial Stability: The Significance and Distinctiveness of Islamic Banking in Malaysia (Working paper): The Levy Economics Institute.

Kasmidou, K., Tanna, S., \& Pasiouras, F. (2005). Determinants of Profitability Domestic UK Commercial Banks: Panel Evidenec from the Period 1995-2002. Economics, Finance and Accounting-Applied Research Working Paper, 1-27.

Kuusela, H., \& Paul, P. (2000). A Comparison of Concurrent and Retrospective Verbal Protocal Analysis. The American Journal of Psychology, 113(3), 387-404.

Lerner, E. M. (1981). Discussion: The Determinants of Bank Interest Margins: Theory and Empirical Evidence. Journal of Financial and Quantitative Analyses, 16, 601-622.

Marliana Abdullah, Shahida Shahimi, \& Abdul Ghafar Ismail. (2011). Operational Risk in Islamic Banks: Examination of Issues. Qualitative Research in Financial Markets, 3(2), 131-151.

Maureen, W., \& Joseph, W. (2014). What Factors Drive Interest Rate Spread of Commercial Banks? Empirical Evidence from Kenya. Review of Development Finance, 4, 73-82.

McShane, R. W., \& Sharpe, I. G. (1984). A Time Series/Cross Section Analysis of the Determinants of Australia Trading Bank Loan/Deposit Interests Margin. Journal of Bank Finance, 9, 115-136. 
Nadi Serhan Aydin. (2017). A quantitative framework for testing the resilience of Islamic finance portfolios under IFSB and Basel capital rules. International Journal of Islamic and Middle Eastern Finance and Management, 10(3), 290-311.

Nicholas, B. (2011). The Competitiveness of Commercial Banks in Ghana. African Development Review, 23(1), 75-87.

Nicolae, P., Bogdan. C., \& Julian, I. (2015). Determinants of Bank's Profitability: Evidence from EU Banking Systems. Procedia Economics and Finance, 20, 518-524.

Oliver, E., Christoph, M., Benedikt, R., \& Marco, W. (2015). Determinants of Bank Interest Margins: Impact of Maturity Transformation. Journal of Banking and Finance, 54, 1-19.

Othman, L. (2015). Penyelidikan Kualitatif: Pengenalan kepada Teori dan Metode. Tanjung Malim, Perak: Penerbit Universiti Pendidikan Sultan Idris.

Panayiotis, P. A., Sophocles, N. B., \& Matthaios, D. D. (2008). Bank-Specific, Industry Specific and Macroeconomic Determinants of Bank Profitability. Journal of International Financial Markets, Institutions \& Money, 18, 121-136.

Patrick, J., \& James, N. (2004). Processing Tracing of Complex Cognitive Work Task. Journal of Occupational and Organizational Psychology, 7(2), 259-280.

Payne, J. W. (1994). Thinking Aloud: Insight into Information Processing. Psychological Science, 5, 241-248.

Porter, M. E. (1979). How Competitive Forces Shape Strategy. Harvard Business Review, 57, 137-145.

Puteri, N.F. N. F., Khairuddin, R., Azila, A. S., \& Sharina, F. H. (2016). Takaful: A Review on Performance, Issues and Challenges in Malaysia. Journal of Scientific Research and Development, 3(4), 71-76.

Rasiah, D. (2010). Review of Literature and Theories on Determinants of Commercial Bank Profitability. Journal of Performance Management, (1), 23-49.

Samy \& Mohamed. (2008). The Determinants of Commercial Bank Interest Margin and Profitability: Evidence from Tunisia. Frontiers in Finance and Economics, (5), 106-130.

Santiago, C. V., \& Francisco, R. F. (2007). The Determinants of Bank Margins in European

Banking. Journal of Banking and Finance, (31), 2043-2063.

Sekaran, U. (2003). Research Methods For Business: A Skill Building Approach $\left(4^{\text {th }}\right.$ ed.). John Wiley $\&$ Sons, Inc.

Sufian, F., \& Abdullah, M. S. (2010). Accessing the Impact of Financial Crisis on Bank Performance. Asean Economic Bulletin, 27(3), 245-262. 
Wasiuzzaman \& Hanimas. (2010). Profitability of Islamic Banks in Malaysia: An Empirical Analysis. Journal of Islamic Economics, Banking and Finance. 6(4), 53-68.

Wong, K. P. (1997). On the Determinants of Bank Interest Margins Under Credit and Interest Rate Risks. Journal of Banking and Finance, (21), 251271. 